\title{
Myrtaceae em restingas no limite norte de distribuição da Mata Atlântica, Brasil
}

\author{
Myrtaceae in the restinga vegetation at the northern limit \\ of the Atlantic coastal forest, Brazil
}

\author{
Ana Raquel de Lima Lourenço ${ }^{1,2}$ \& Maria Regina de Vasconcellos Barbosa ${ }^{1,2,3}$
}

\begin{abstract}
Resumo
Myrtaceae é uma das famílias mais ricas em espécies nas restingas brasileiras. O objetivo desse trabalho foi levantar a riqueza e realizar o tratamento taxonômico das espécies de Myrtaceae presentes em remanescentes de restinga situados na divisa entre os Estados da Paraíba e Rio Grande do Norte, no limite norte de distribuição da Mata Atlântica. Foram registradas 23 espécies, sendo a subtribo Eugeniinae a mais diversa, com 11 espécies, seguida de Myrciinae com 8 e Myrtinae com 4. É apresentada uma chave para identificação das espécies, bem como descrições, ilustrações e dados relativos à fenologia e distribuição geográfica.
\end{abstract}

Palavras-chave: Myrtaceae, Mata Atlântica, restinga, nordeste do Brasil.

\begin{abstract}
Myrtaceae are one of the richest families in the Brazilian restinga vegetation (open savannas or low forests over sand near the coast). The purpose of this study was to evaluate the species richness and present a taxonomic treatment of all Myrtaceae species occurring in restinga remnants near the border of Paraíba and Rio Grande do Norte at the northern limit of the Atlantic coastal forest. We identified 23 species of Myrtaceae, 11 in subtribe Eugeniinae, 8 in Myrciinae, and 4 in Myrtinae. A key to species, descriptions, illustrations, as well as phenological and geographic distribution data are provided.
\end{abstract}

Key words: Myrtaceae, Atlantic coastal forest, restinga, northeastern Brazil.

\section{Introdução}

Myrtaceae Juss. compreende cerca de 130 gêneros, com 5.671 espécies aceitas no mais recente checklist mundial (Govaerts et al. 2008). Para o Brasil são citadas 927 espécies em 24 gêneros (Sobral et al. 2012) As Myrtaceae brasileiras pertencem à tribo Myrteae, que forma um grupo filogeneticamente coeso (Wilson et al. 2001), dividido em três subtribos: Eugeniinae, Myrciinae e Myrtinae, com base na morfologia dos embriões (Berg 1957, 1858, 1959).

Presente em diversos biomas brasileiros é na Mata Atlântica que a família se destaca como uma das de maior riqueza (Reitz et al. 1978; Peixoto \& Gentry 1990; Barroso \& Peron 1994; Silva et al. 1994; Barroso \& Peixoto 1995; Araújo 2000), inclusive nos escassos estudos realizados na floresta atlântica e restingas da região Nordeste (Freire 1990; Oliveira-Filho \& Carvalho 1993; Zickel et al. 2004). Essa escassez de estudos ocasiona uma subestimação do real número de espécies que ocorrem na região, e devido à falta de estudos específicos com Myrtaceae, uma grande quantidade de material indeterminado encontra-se nos herbários nordestinos.

Este trabalho teve como objetivo avaliar a riqueza e apresentar o tratamento taxonômico da família Myrtaceae em dois remanescentes de restinga na divisa entre os estados do Rio Grande do Norte e da Paraíba. Esta região está localizada

\footnotetext{
${ }^{1}$ Universidade Federal de Pernambuco, Centro de Ciências Biológicas, Dep. Botânica, Programa de Pós Graduação em Biologia Vegetal; R. Prof. Nelson Chaves s/n, Cidade Universitária, 50670-901, Recife, PE, Brasil. raquelraquell@gmail.com

${ }^{2}$ Universidade Federal da Paraíba, Centro de Ciências Exatas e da Natureza, Dep. Sistemática e Ecologia, C.P. 5065, 58051-970, João Pessoa, PB, Brasil.

${ }^{3}$ Autor para correspondência: mregina@dse.ufpb.br
} 
no limite norte de distribuição da Mata Atlântica, onde as restingas apresentam-se adjacentes aos tabuleiros litorâneos, muitas vezes confundindose com estes.

\section{Material e Métodos}

\section{Caracterização da área}

A área de estudo localiza-se no limite dos Estados do Rio Grande do Norte e Paraíba, onde foram estudados dois remanescentes de vegetação de restinga. O primeiro deles, a RPPN Mata Estrela, situa-se no município de Baía Formosa, litoral sul do Rio Grande do Norte. Trata-se do maior remanescente de Mata Atlântica do estado e o maior sobre dunas litorâneas do País, contando com uma área total de 2.039 hectares. O segundo é uma área particular em Mataraca, extremo norte do litoral da Paraíba, contígua ao município de Baia Formosa. A vegetação da área é classificada como restinga, e o tipo de solo predominante em ambas as áreas são as areias quartzosas e as areias quartzosas marinhas (EMBRAPA 2006). As duas áreas são adjacentes, distando cerca de $20 \mathrm{~km}$. O clima local é do tipo As', segundo a classificação de Köppen (Jacomine et al. 1971), considerado como um clima tropical chuvoso, com primavera e parte do verão seco e estação chuvosa se adiantando para o outono e inverno, apresentando uma precipitação média anual de $1.700 \mathrm{~mm}$.

\section{Metodologia}

As expedições a campo ocorreram no período de junho de 2008 a agosto de 2009, com uma freqüência mensal, buscando percorrer todas as formações vegetais presentes em ambas as áreas. Foi possível reconhecer, de acordo com a classificação proposta por Oliveira-Filho e Carvalho (1993), sete formações vegetais distintas: restinga herbácea, restinga arbustiva, restinga arbórea, ecótono savana-restinga, formação ripária arbustiva, savana arborizada e formação estuarina arbórea, que foram percorridas para a constatação da ocorrência das espécies de Myrtaceae, exceto as duas últimas, por não se tratarem do foco do trabalho.

O material coletado foi depositado no herbário JPB com duplicatas no herbário UFP e RB. Foram consultadas as coleções dos herbários ALCB, ASE, EAN, HUEFS, IPA, JPB,
PEUFR, RB, UFRN e UFP a fim de verificar a distribuição geográfica das espécies, dados acerca da floração e frutificação, bem como informações complementares. As siglas dos herbários estão de acordo com Thiers (2010). As descrições dos gêneros foram feitas com base exclusivamente nas espécies ocorrentes na área de estudo. Para a descrição dos dados dendrológicos foram utilizadas as definições de Ribeiro et al. (1999). $\mathrm{O}$ indumento foi descrito de acordo os termos adaptados de Font Quer (1979) e os conceitos de morfologia foliar seguiram o trabalho de Stearn (1978) e Hickey (1973).

Para a descrição das inflorescências foram adotados conceitos utilizados em trabalhos anteriores sobre a família, como por exemplo, o termo fascículo, adaptado de Landrum \& Kawasaki (1997), para quando um racemo apresenta o comprimento do eixo encurtado. De Barroso et al. (1991) retirou-se o conceito de "racemo stenocalyx", inflorescência encontrada em algumas espécies de Eugenia L., caracterizada por um ramo vegetativo que tem nós férteis na porção inferior, protegido por brácteas agrupadas imbricadamente. A parte inferior desse ramo é precoce, suas flores abrindo-se primeiro e somente depois a parte vegetativa superior começa a se desenvolver. Por esse motivo, esse tipo de inflorescência também é denominado racemo precoce (Faria Júnior 2010). Os termos prófilos, ferófilos, antopódios e os demais tipos de inflorescências foram descritos de acordo com Briggs \& Johnson (1979). Os frutos e embriões foram reconhecidos e descritos de acordo com Barroso et al. (1999).

\section{Resultados e Discussão}

A família Myrtaceae está representada na área de estudo por 23 espécies distribuídas em 6 gêneros. A subtribo mais diversa foi Eugeniinae (Eugenia e Myrciaria O. Berg), com 11 espécies, seguida de Myrciinae (Calyptranthes e Myrcia DC. ex Guill.), com 8 espécies no total. A subtribo Myrtinae (Campomanesia Ruiz \& Pav. e Psidium L.) apresentou 4 espécies.

O gênero mais diverso foi Eugenia com 9 espécies, seguido de Myrcia com 7, Myrciaria, Campomanesia e Psidium apresentando 2 espécies cada, sendo Calyptranthes o que apresentou a menor riqueza, com uma única espécie. 
Das seis formações vegetais estudadas, as que apresentaram o maior número de espécies de Myrtaceae foram a restinga arbustiva com 16 e a restinga arbórea com 13 espécies. No ecótono savana-restinga foram registradas 6 espécies, e na restinga herbácea 4 . A área de formação pioneira ripária arbustiva apresentou apenas uma espécie, a do gênero Calyptranthes, geralmente relacionada a esse tipo de ambiente (OliveiraFilho \& Carvalho 1993).

\section{Chave para identificação das espécies de Myrtaceae presentes nas restingas no limite norte de distribuição da Mata Atlântica (Subtribos Eugeniinae, Myrciinae e Myrtinae)}

1. Inflorescências em racemos simples ou "stenocalyx", às vezes muito reduzidos, com eixo encurtado formando um fascículo ou aparentando flores solitárias.

2. Flores com antopódio curto (0,5-1 mm compr.), cálice decíduo após a antese, fruto bacídio.

3. Folhas com ápice longo acuminado, pecíolo 2-6 mm compr. .... 2.1 Myrciaria floribunda

3'. Folhas com ápice agudo, pecíolo até $1 \mathrm{~mm}$ compr. 2.2 Myrciaria tenella

2'. Flores com antopódio $>1 \mathrm{~mm}$ compr., cálice persistente, frutos de outros tipos.

4. Hipanto prolongado acima do ovário; ovário 5-19 locular

5.1 Campomanesia aromatica

4'. Hipanto não prolongado acima do ovário; ovário bilocular.

5. Inflorescências em racemos simples, frutos elipsoides

1.1 Eugenia candolleana

5'. Inflorescências em racemos "stenocalyx" ou fascículos (às vezes reduzidos), frutos globosos ou subglobosos.

6. Inflorescências em racemos "stenocalyx".

7. Flores com hipanto e frutos 8-costados

1.8 Eugenia uniflora

7'. Flores com hipanto e frutos não costados.

8. Prófilos foliáceos, cordiformes, persistentes

' Prófilos não foliáceos, com outras formas, decíduos.

9. Folhas ovadas ou elípticas, ápice agudo ou curto-acuminado; frutos globosos ou subglobosos, vilosos ou velutinos, 25-30 $\times 23-32 \mathrm{~mm}$, amarelos quando maduros ..... 1.9 Eugenia sp.

9'. Folhas elípticas ou estreito-obovadas, ápice agudoarredondado, ligeiramente retuso; frutos subglobosos, glabros, 5-6 $\times 8 \mathrm{~mm}$, vináceos ou negros quando maduros

1.5 Eugenia ligustrina

6'. Inflorescências em fascículos.

10. Folhas ovadas com ápice agudo

1.4 Eugenia hirta

10'. Folhas e ápice de outras formas.

11. Folhas com ápice acuminado a longo acuminado, cálice ocultando o globo petalífero no botão floral 1.2 Eugenia excelsa

11'. Folhas com ápice curto-acuminado, obtuso, obtuso-curto-acuminado ou arredondado; cálice não ocultando o globo petalífero no botão floral.

12. Folhas elípticas, raro elíptico-lineares, base aguda ou cuneada; botões florais subglobosos, com lobos desiguais entre si; frutos vermelhos quando maduros 1.6 Eugenia punicifolia

12'. Folhas obovadas ou orbiculadas, base arredondada; botões florais globosos, com lobos iguais entre si; frutos negros quando maduros 1.7 Eugenia umbelliflora 
1'. Inflorescências tirsoides, panículas, dicásios, mônades ou díades.

13. Inflorescências tirsoides ou panículas.

14. Cálice totalmente fechado no botão floral, apiculado, desprendendo-se em forma de caliptra 3.1 Calyptranthes brasiliensis

14'. Sem o conjunto de caracteres.

15. Hipanto não prolongado acima do ovário.

16. Folhas com indumento brúneo-avermelhado na face abaxial; frutos globosos ou subglobosos

4.1 Myrcia bergiana

16'. Folhas com indumento gríseo a pardacento na face abaxial; frutos elipsoides

17. Folhas de ápice acuminado ou obtuso-curto-acuminado, 70-145 × 35-50 mm, pecíolo 3-6 mm compr.; botões florais globosos, 3-4 mm compr., lobos arredondados ou deltoides 4.5 Myrcia splendens

17'. Folhas de ápice longo acuminado, 40-65 × 15-24 mm, pecíolo 1,5-2 mm compr.; botões florais obcônicos, $2 \mathrm{~mm}$ compr., lobos semicirculares

4.6 Myrcia sylvatica

15'. Hipanto prolongado acima do ovário.

18. Ovário trilocular

4.2 Myrcia guianensis

18'. Ovário bilocular.

19. Inflorescências tirsoides; frutos alaranjados quando maduros

4.7 Myrcia tomentosa

19'. Inflorescências em panículas; frutos negros quando maduros.

20. Nervura intramarginal ausente; cálice não ocultando o globo petalífero no botão floral; hipopódio 10-20 mm compr. 4.4 Myrcia multiflora

20'. Nervura intramarginal até 0,5 do bordo; cálice ocultando parcialmente o globo petalífero no botão floral; hipopódio $35 \mathrm{~mm}$ compr.

4.3 Myrcia lundiana

13'. Inflorescências dicásios, mônades ou díades.

21. Cálice totalmente aberto no botão floral

5.2 Campomanesia dichotoma

21'. Cálice total a parcialmente fechado no botão floral, com lobos irregulares ou caliptra.

22. Folhas com ápice obtuso, arredondado, mucronado ou curto-acuminado; nervura marginal não definida 6.1 Psidium guineense

22'. Folhas com ápice longo acuminado ou agudo; nervura marginal 1-3 mm do bordo .... 6.2 Psidium oligospermum

Myrtaceae Juss., Genera Plantarum: 322-323. 1979.

Plantas arbustivas ou arbóreas, com córtex esfoliante, glabras ou pilosas, indumento simples ou dibraquiado; canais oleíferos presentes na forma de pequenos pontos translúcidos (pontuações), aparecendo nas folhas, flores, frutos e sementes; folhas simples, opostas, de bordo inteiro, nervuras secundárias broquidódromas, nervuras marginais e intramarginais definidas ou não; flores reunidas em inflorescências cimosas ou racemosas, actinomorfas, diclamídeas, dialipétalas, tetrâmeras, pentâmeras ou com pétalas reduzidas ou ausentes, andróginas, polistêmones, ovário ínfero; fruto do tipo bacóide ou variações deste, com cálice ou cicatriz deste presente no ápice; sementes de 1 a numerosas.

\section{Subtribo Eugeniinae O. Berg (Eugenia e Myrciaria)}

Embrião eugenioide, com cotilédones carnosos e espessos, mais ou menos planoconvexos e separados, ou levemente conados, ou ainda fusionados em uma massa homogênea, o hipocótilo indistinto ou distinto e muito menor que os cotilédones.

\section{Eugenia L., Sp. Pl. 1: 470. 1753.}

Subarbustos ou árvores, glabros, puberulentos ou tomentosos, indumento simples. Fascículos, racemos simples ou "stenocalyx", às vezes muito reduzidos aparentando flores isoladas, terminais ou axilares; prófilos e ferófilos decíduos ou persistentes na antese; flores tetrâmeras, pétalas 
brancas; cálice aberto no botão floral, com lobos iguais ou desiguais, ocultando ou não o globo petalífero; hipanto não prolongado acima do ovário; ovário bilocular com mais de 3 óvulos/lóculo. Fruto bacáceo, globoso a subgloboso com cálice persistente; sementes 1-3, testa membranácea, cartácea, coriácea ou fibrosa.

Um dos maiores gêneros de Myrtaceae, o número de espécies é estimado em mais de 500 para a América do Sul (Mc Vaugh 1968) e cerca de 350 para o Brasil (Sobral et al. 2012). Distribui-se desde o México e Caribe até o norte da Argentina (Landrum \& Kawasaki 1997).

1.1 Eugenia candolleana DC., Prodr. 3: 281. 1828. Arbustos de 2-3 m altura, inflorescências, flores e frutos tomentosos a pubérulos, indumento albo-ferrugíneo; tronco com casca externa acinzentada, esfoliando-se em placas. Folhas elípticas ou levemente orbiculadas, ápice agudo a longo acuminado, base cuneada, raro arredondada, bordo ligeiramente revoluto, cartáceas, discolores, brilhantes na face adaxial, opacas na abaxial, pontuações translúcidas densas não visíveis a olho nu na face adaxial, visíveis na abaxial; 45-70 $\times 20-35 \mathrm{~mm}$; nervura principal impressa na face adaxial, proeminente na abaxial; nervuras secundárias inconspícuas, pouco visíveis na face adaxial, visíveis na abaxial, 6-10 pares; nervura marginal $2-4 \mathrm{~mm}$ do bordo, nervura intramarginal ca. $1 \mathrm{~mm}$ do bordo; pecíolo, 4-6 mm compr., levemente canaliculado. Racemos simples, axilares em nós folhosos basais, 6-8 pares de flores, eixo 15-25 mm compr.; ferófilos arredondados a triangulares, 0,5-1 $\mathrm{mm}$ compr., ciliados; antopódio 4-9 mm compr.; prófilos arredondados a triangulares, conados, naviculados, $0,5-1 \mathrm{~mm}$ compr., ciliados, persistentes. Botões florais globosos, 2 mm diâm.; cálice ocultando o globo petalífero, lobos suborbiculares ou arredondados, $2 \times 1-2 \mathrm{~mm}$, desiguais, com dois maiores e dois menores, ciliados, não reflexos após a antese; hipanto não costado longitudinalmente; ovário com 3 óvulos/lóculo. Frutos elipsoides, não costados, 4-5 × 2-3 mm., purpúreos quando maduros; semente 1 , comprimida longitudinalmente, $5 \times 2$ $\mathrm{mm}$, testa coriácea.

Material examinado: PARAÍBA: Mataraca, restinga arbórea, 30.IV.2009, fl. e fr., P.C. Gadelha Neto 2588 (JPB). RIO GRANDE DO NORTE: Baía Formosa, Mata Estrela, restinga arbustiva, 27.V.2006, fr., A.R. Lourenço 178 (JPB).
A espécie distribuiu-se no Rio Grande do Norte, Paraíba, Pernambuco, Alagoas, Sergipe, Bahia, Rio de Janeiro, São Paulo, Goiás e Amazonas, em ambientes de Mata Atlântica, Amazônia e Cerrado. Em Mataraca foi encontrada na restinga arbórea e na Mata Estrela foi encontrada na restinga arbustiva.

Caracteriza-se pelos antopódios variando gradualmente em comprimento na inflorescência e pelos frutos elipsoides, fortemente glandulares. Floresce em abril, frutifica em abril e maio.

1.2 Eugenia excelsa O. Berg, Fl. bras. 14(1): 277. 1857.

Arvoretas até $6 \mathrm{~m}$ de altura, glabras; tronco com casca externa castanho-acinzentada, áspera. Folhas elípticas ou ovado-elípticas, ápice acuminado a longo acuminado, base cuneada, bordo ligeiramente revoluto, coriáceas, discolores, face adaxial brilhante, abaxial opaca, pontuações translúcidas visíveis a olho nu na face abaxial, não visíveis na adaxial; $28-47 \times 12-18 \mathrm{~mm}$; nervura principal impressa ou levemente proeminente na face adaxial, proeminente na abaxial; nervuras secundárias pouco visíveis, 6-8 pares; nervura marginal ca. $1 \mathrm{~mm}$ do bordo, nervura intramarginal ausente; pecíolo 2-3 mm compr., canaliculado. Fascículos axilares em nós folhosos ou áfilos, 2-4 flores, eixo 1-1,5 mm compr.; ferófilos oblongos ou curto-oblongos, 1-2 mm compr., ciliados; antopódio 4-7 mm compr.; prófilos oblongos, não conados, até $1 \mathrm{~mm}$ compr., ciliados, decíduos. Botões florais obcônicos ou globosos, 2,5-3 mm diâm.; cálice ocultando o globo petalífero, lobos ovados, 1,5-2 × 1,5-2 mm, iguais entre si, ciliados, não reflexos após a antese; hipanto não costado longitudinalmente; ovário com 6 óvulos/ lóculo. Frutos globosos, não costados, até ca. de $5 \mathrm{~mm}$ diâm., negros quando maduros, sementes não vistas.

Material examinado: RIO GRANDE DO NORTE: Baía Formosa, Mata Estrela, restinga arbustiva, 4.VIII.2004, fl., A.R.Lourenço 50 (JPB); 22.I.2009, fl., A.R.Lourenço 220 (JPB).

Material adicional examinado: PARAÍBA: Santa Rita, tabuleiro litorâneo, 19.III.1996, fr., M.F. Agra (JPB).

Apresenta distribuição no Rio Grande do Norte, Pernambuco, Alagoas, Bahia, Pará, Espírito Santo, Rio de Janeiro, São Paulo, Paraná e Santa Catarina, em ambientes de Mata Atlântica. 
$\mathrm{Na}$ Mata Estrela ocorre na restinga arbustiva. A espécie é facilmente reconhecida no campo pelas folhas elípticas ou ovado-elípticas de ápice acuminado a longo acuminado, brilhantes na face adaxial. Floresce de agosto a abril.

\subsection{Eugenia glandulosa Cambess., Fl. bras.} Merid. 2: 352. 1832.

Fig. 1a

Árvore aprox. 4-5 m de altura, ramos, folhas, pecíolos, inflorescência, flores e frutos velutinos, esparso-velutinos ou glabrescentes, tricomas dibraquiados; tronco com casca externa desprendendo-se em lâminas papiráceas. Folhas obovadas ou elíptico-obovadas, ápice obtusoacuminado ou agudo-acuminado, base cuneada a revoluta, bordo revoluto, coriáceas, discolores, brilhantes na face adaxial, opacas na abaxial, pontuações translúcidas densas não visíveis a olho nu; 75-105 × 35-45 mm; nervura principal sulcada na face adaxial, proeminente na abaxial; nervuras secundárias inconspícuas, pouco visíveis, $12-14$ pares; nervura marginal $2-3 \mathrm{~mm}$ do bordo, nervura intramarginal $0,5-1 \mathrm{~mm}$ do bordo; pecíolo 10-13 × 1-2 mm, canaliculado. Racemos "stenocalyx" axilares em nós folhosos terminais, 2-4 pares de flores, eixo $4 \mathrm{~mm}$ compr.; ferófilos elíptico-lineares, 8-13 × 2-5 $\mathrm{mm}$, ciliados; antopódio 5-50 $\mathrm{mm}$ compr.; prófilos foliáceos, cordiformes e assimétricos, não conados, $12-20 \times 11-15 \mathrm{~mm}$, persistentes. Botões florais globosos, 7-9 × 9-10 mm; cálice ultrapassando o globo petalífero, porém não o ocultando, lobos ovados a triangulares, $11-17 \times$ 11-15 mm, desiguais, com dois maiores e dois menores, ciliados, não reflexos após a antese; hipanto não costado longitudinalmente; ovário com mais de 15 óvulos/lóculo. Frutos globosos ou subglobosos, ca. $40 \mathrm{~mm}$ diâm., amarelos quando maduros; sementes 2, ca. $3 \mathrm{~mm}$, plano-convexas; testa dura, fibrosa.

Material examinado: PARAIIBA: Mataraca, restinga arbustiva, 5.XI.2008, f1. e fr., P.C. Gadelha Neto 2478 (JPB).

Conhecida até então somente para o Cerrado de Goiás, Tocantins e Minas Gerais, foi encontrada em Mataraca, na área de restinga arbustiva, ambiente este semelhante fisionomicamente ao do Cerrado. Caracteriza-se principalmente pelas flores vistosas e pelo par de prófilos grandes, foliáceos. Seu fruto é comestível. Floresce e frutifica em novembro.
1.4 Eugenia hirta O. Berg, Fl. bras. 14(1): 574. 1857.

Arvoretas de aprox. 1,6 m altura, ramos hirtos a tomentosos, folhas pubescentes a glabras, inflorescências pubescentes e frutos glabrescentes; tronco com casca externa castanha. Folhas ovadas, ápice agudo, base arredondada ou levemente cordada, bordo não revoluto ou ligeiramente revoluto, cartáceas, discolores, opacas em ambas as faces, pontuações translúcidas visíveis a olho nu na face abaxial, não visíveis na adaxial; $23-50$ $\times$ 20-34 mm; nervura principal impressa na face adaxial, proeminente na abaxial; nervuras secundárias inconspícuas em ambas as faces, 5-8 pares; nervura marginal 1,5-4 $\mathrm{mm}$ do bordo, nervura intramarginal ausente; pecíolo 1-2 mm compr. Fascículos axilares reduzidos em nós folhosos basais, $1-2$ pares de flores, eixo $<1 \mathrm{~mm}$ compr.; ferófilos triangulares ou arredondados, 0,5 mm compr., ciliados; antopódio 5-19 mm compr.; prófilos triangulares, não conados, $0,5 \mathrm{~mm}$ compr., ciliados, persistentes. Botões florais globosos, subglobosos ou ligeiramente piriformes, $2-3 \mathrm{~mm}$ diâm.; cálice não ocultando o globo petalífero, lobos oblongos, 2-3 × 1-2 mm, desiguais, com dois maiores e dois menores, ciliados, não reflexos após a antese; hipanto não costado longitudinalmente; ovário com 4-5 óvulos/lóculo. Frutos globosos, não costados, 4-6 mm diâm., vermelhos a negros quando maduros; semente 1, 1-4 mm diâm., testa cartácea, maleável.

Material examinado: PARAÍBA: Mataraca, restinga arbórea, 23.IX.2009, fl. e fr., A.R. Lourenço 196 (JPB). RIO GRANDE DO NORTE: Baía Formosa, Mata Estrela, restinga arbórea, 3.IX.2004, fl., M.R. Barbosa 3008 (JPB).

Espécie presente no Rio Grande do Norte, Paraíba, Pernambuco, Sergipe, Bahia e Espírito Santo, na Mata Atlântica. Na área de estudo foi encontrada na restinga arbórea.

Pode ser reconhecida pelo pecíolo curto e flores inconspícuas, sendo comum no sub-bosque da restinga arbórea. Floresce de maio a dezembro, frutifica de junho a agosto.

1.5 Eugenia ligustrina (Sw.) Willd., Sp. Pl., ed. 4 (2): 962.1799.

Fig. 1b

Arbustos de aprox. 2-3 m de altura, glabros, exceto pelos ramos jovens e pecíolos puberulentos; tronco com casca externa grísea, áspera, esfoliando-se em placas. Folhas elípticas ou estreito-obovadas, ápice agudo-arredondado, 

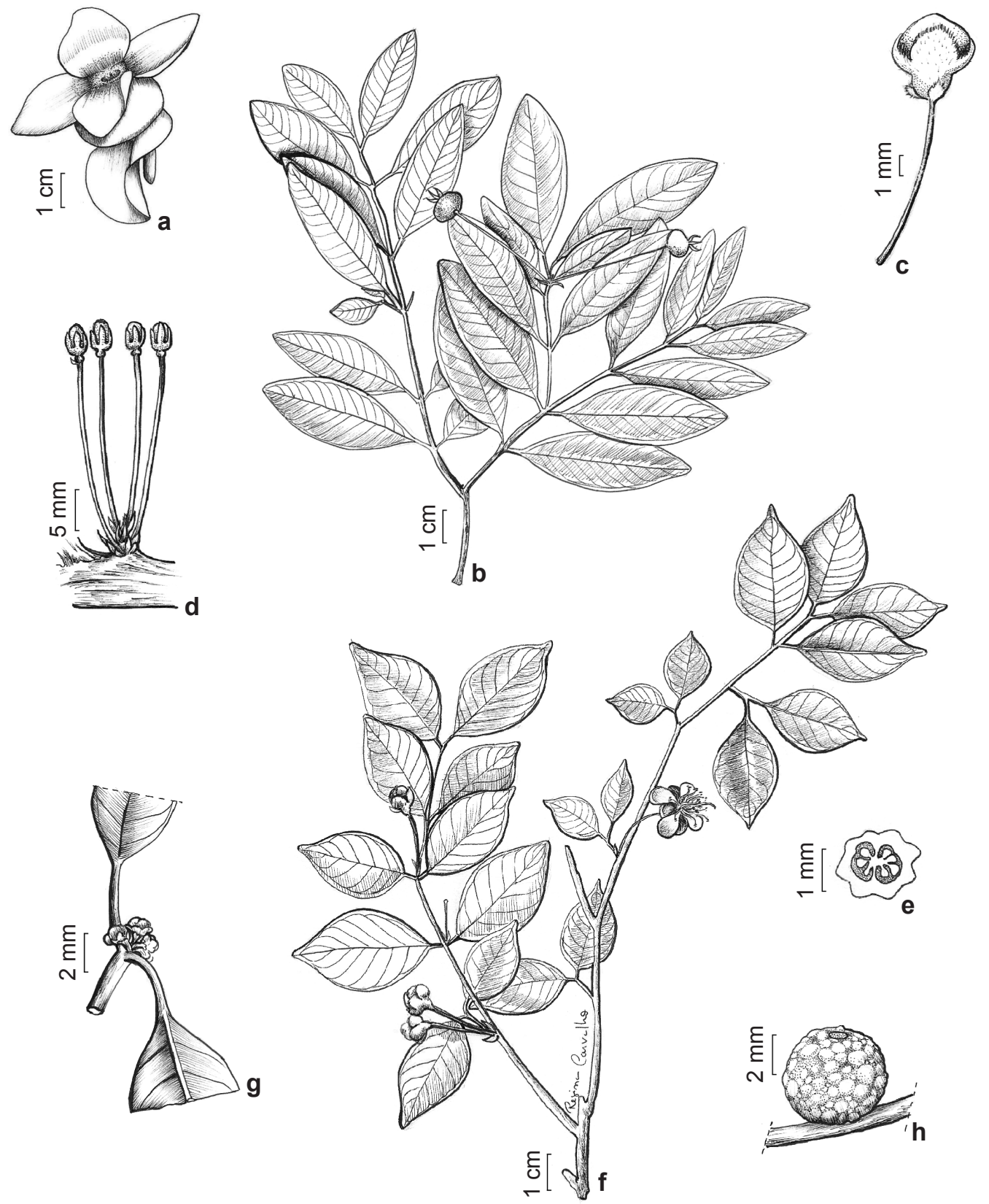

Figura 1 - Subtribo Eugeniinae- a. Eugenia sp. - a. ramo com inflorescências. b. E. ligustrina - b. ramo com frutos. c. E. glandulosa - c. fruto imaturo com profilo foliáceo. d. E. punicifolia - d. botão floral; e-f. E. uniflora-e. racemo "stenocalyx" reduzido; f. seção transversal do ovário. g-h. Myrciaria floribunda - g. detalhe do ramo mostrando o fascículo axilar; h. fruto com cicatriz circular apical (a. Gadelha Neto 1981; b. Lourenço 244; c. Gadelha Neto 2478; d-Lourenço 213; e-f. Lourenço 276; g-h. Lourenço 204).

Figure 1 - Subtribe Eugeniinae- a. Eugenia sp. - a. stem with inflorescences. b. E. ligustrina - b. stem with fruits. c. E. glandulosa - c. imature fruit with foliaceous prophyll. d. E. punicifolia - d. floral bud. e-f. E. uniflora - e. reduced "stenocalyx" raceme; f- transversal section of the ovary. g-h. Myrciaria floribunda - g. detail of stem, showing the axillary fascicle; h. fruit with circular apical scar (a. Gadelha Neto 1981; b. Lourenço 244; c. Gadelha Neto 2478; d- Lourenço 213; e-f. Lourenço 276; g-h. Lourenço 204). 
ligeiramente retuso, base atenuada ou cuneada, bordo revoluto, cartáceas a coriáceas, discolores, brilhantes na face adaxial, opacas na abaxial, pontuações translúcidas densas não visíveis a olho nu na face adaxial, pouco visíveis na abaxial; $40-58 \times 17-25 \mathrm{~mm}$; nervura principal sulcada na face adaxial, proeminente na abaxial; nervuras secundárias 14-19 pares, visíveis na face adaxial, inconspícuas na abaxial; nervura marginal 0,5-1 $\mathrm{mm}$ do bordo, nervura intramarginal ausente; pecíolo 2-4 mm compr. Racemos "stenocalyx" terminais ou em nós folhosos basais ou áfilos, ca. de 3 pares de flores, eixo até $5 \mathrm{~mm}$ compr.; ferófilos arredondados, lineares ou elípticos, 2-7 mm compr., levemente ciliados; antopódio 15-38 mm compr.; prófilos lineares, não conados, 2-3 mm compr., ciliados, decíduos. Botões florais oblongos ou globosos, 4-5 mm compr.; cálice ocultando parcialmente o globo petalífero, lobos oblongos, 2,5-3 mm compr., iguais entre si, reflexos após a antese; hipanto não costado longitudinalmente; ovário não observado. Frutos subglobosos, não costados, glabros, 5-6 $58 \mathrm{~mm}$, vináceos ou negros quando maduros; sementes 1-2, até ca. de $7 \mathrm{~mm}$ diâm., testa membranácea ou cartácea.

Material examinado: PARAIÍBA: Mataraca, restinga arbórea, 9.III.2009, fr., A.R. Lourenço 243 (JPB); fr., A.R. Lourenço 244 (JPB); restinga arbustiva, 12.I.2011, fl., R.A. Pontes et al. 672 (JPB). RIO GRANDE DO NORTE: Baía Formosa, Mata Estrela, restinga arbórea, 21.I.2009, fr., A.R. Lourenço 215 (JPB).

Material adicional examinado: PARAÍBA: Alagoinha, Estação experimental, 29.I.1943, fl., L.P. Xavier 1162 (JPB).

Espécie distribui-se no Pará, Rio Grande do Norte, Paraíba, Pernambuco, Bahia, Minas Gerais, Espírito Santo, Rio de Janeiro, São Paulo, Paraná e Santa Catarina, em áreas de Mata Atlântica, Amazônia e Cerrado. Na área de estudo foi coletada na restinga arbórea e arbustiva.

Reconhecida em campo pelas folhas verdeescuro brilhantes na face adaxial e frutos negros quando maduros, com cálice na mesma cor. Floresce de outubro a março, frutifica de janeiro a abril.

1.6 Eugenia punicifolia (Kunth) DC., Prod. 3:267. 1828.

Fig. 1c

Subarbustos a arvoretas de até $5 \mathrm{~m}$ de altura, ramos jovens pubescentes, face adaxial e abaxial das folhas e nervura principal puberulentas ou glabras, inflorescências puberulentas, indumento castanho ou esbranquiçado; tronco com casca externa áspera. Folhas elípticas, raro elípticolineares, ápice curto-acuminado ou obtusocurto-acuminado, base aguda ou cuneada, bordo ligeiramente revoluto, cartáceas a coriáceas, discolores, face adaxial brilhante ou opaca, face abaxial opaca, pontuações translúcidas visíveis ou não, esparso a mediamente pontuadas; $21-75$ $\times$ 9-40 $\mathrm{mm}$; nervura principal impressa ou ligeiramente proeminente na base da face adaxial, proeminente ou impressa na abaxial; nervuras secundárias às vezes inconspícuas, 5-8 pares; nervura marginal $1-3 \mathrm{~mm}$ do bordo, nervura intramarginal ausente; pecíolo 1-5 mm compr. Fascículos axilares em nós folhosos basais ou terminais, 2-6 flores, eixo 1-3 $\mathrm{mm}$ compr.; ferófilos triangulares ou ovados, $0,5-1 \mathrm{~mm}$ compr., ciliados; antopódio 4-20 mm compr.; prófilos triangulares ou arredondados, não conados, 0,5-1 $\mathrm{mm}$ compr., ciliados, persistentes. Botões florais subglobosos, $2 \times 3 \mathrm{~mm}$; cálice não ocultando o globo petalífero, lobos arredondados ou oblongos, $1,5-3 \times 1,5-3 \mathrm{~mm}$, desiguais, com dois maiores e dois menores, ciliados, não reflexos após a antese; hipanto não costado longitudinalmente; ovário com ca. de 15 óvulos/lóculo. Frutos globosos ou ligeiramente elipsoides, não costados, até $9 \mathrm{~mm}$ diâm., vermelhos quando maduros; semente 1-3, 5-7 mm diâm., testa coriácea.

Material examinado: PARAÍBA: Mataraca, Millennium Inorganic Chemicals LTDA, restinga arbustiva, 4.X.2007, fr., I.B. Lima 804 (JPB); restinga herbácea, 27.VIII.2008, fl., A.R. Lourenço 192 (JPB); restinga arbórea, 23.IX.2008, fr., A.R. Lourenço 199 (JPB); ecótono savana-restinga, 30.IX.2008, fr., $A . R$. Lourenço 209 (JPB); restinga arbustiva, 20.I.2009, fr., A.R. Lourenço 213 (JPB); borda de restinga arbórea, 9.III.2009, fl., A.R. Lourenço 233 (JPB). RIO GRANDE DO NORTE: Baía Formosa, Mata Estrela, restinga arbórea, 28.III.2006, fl., A.R. Lourenço 141 (JPB).

Amplamente distribuída no Brasil, na Amazônia, Cerrado, Mata Atlântica e Caatinga. $\mathrm{Na}$ área de estudo foi encontrada nas fisionomias de restinga herbácea, arbustiva, arbórea e no ecótono savana-restinga. Espécie que apresenta uma grande variação morfológica, o que geralmente ocasiona confusão na sua identificação. Floresce e frutifica ao longo de quase todo ano, predominando nos meses de novembro a maio. 
1.7 Eugenia umbelliflora O. Berg, Fl. bras. 14(1): 290. 1857.

Arbustos até ca. de $2 \mathrm{~m}$ de altura, glabros; tronco com casca externa grísea, áspera. Folhas obovadas ou orbiculadas, ápice arredondado, obtuso ou obtuso- curto-acuminado, base arredondada, bordo revoluto, coriáceas, discolores, opacas ou brilhantes na face adaxial, opacas na abaxial, pontuações translúcidas densas não visíveis a olho nu; 40-70 × 30-55 mm; nervura principal plana ou sulcada na face adaxial, proeminente na abaxial; nervuras secundárias 7-10 pares; nervura marginal 2-4 $\mathrm{mm}$ do bordo, nervura intramarginal ausente; pecíolo 2-6 $\mathrm{mm}$ compr. Fascículos axilares em nós folhosos ou áfilos, 2-4 flores, eixo ca. de $1 \mathrm{~mm}$ compr.; ferófilos arredondados, ca. 0,5 $\mathrm{mm}$ compr., ciliados; antopódio 6-10 $\mathrm{mm}$ compr.; prófilos triangulares a arredondados, 1-1,5 mm compr., não conados, ciliados, persistentes, às vezes decíduos. Botões florais globosos, ca. de $4 \mathrm{~mm}$ diâm.; cálice não ocultando o globo petalífero, lobos arredondados, $1 \mathrm{~mm}$ compr., iguais entre si, ciliados, não reflexos após a antese; hipanto não costado longitudinalmente; ovário não visto. Frutos globosos, não costados, até ca. de $10 \mathrm{~mm}$ diâm., negros quando maduros.

Material examinado: PARAÍBA: Mataraca, Millennium Inorganic Chemicals LTDA, restinga arbustiva, 18.X.2007, fr., I.B. Lima 862 (JPB). RIO GRANDE DO NORTE: Baía Formosa, Mata Estrela, restinga arbustiva, 3.IX.2004, fr., M.R. Barbosa 3039 (JPB).

Material adicional examinado: BRASIL. BAHIA: Massarandupió, 29.III.2001, fl., M.L. Guedes 8115 (HUEFS).

Distribui-se no Rio Grande do Norte, Paraíba, Bahia, Rio de Janeiro, Espírito Santo, São Paulo e Santa Catarina, na Mata Atlântica e Caatinga. $\mathrm{Na}$ área de estudo ocorre na formação arbustiva e no limite desta com a formação herbácea. É frequentemente identificada como Eugenia rotundifolia Casar. nas coleções de herbário, porém, E. rotundifolia é um nome ilegítimo, devido à existência de um homônimo mais antigo, sendo E. umbelliflora o nome correto a ser adotado. E. cyclophylla, nome sinonimizado em E. umbeliflora, foi o mais encontrado nas coleções do nordeste, devido a ser o nome utilizado anteriormente para a espécie nas restingas dessa região. Floresce de fevereiro a junho, frutifica de abril a dezembro.
1.8 Eugenia uniflora L., Sp. Pl. 1:470-471. 1753.

Fig. 1d-e

Arbustos ou arvoretas até $5 \mathrm{~m}$ de altura, glabros; tronco com casca externa grísea. Folhas ovadas ou elípticas, ápice acuminado ou agudo, base arredondada, obtusa ou cordada, bordo não revoluto, cartáceas a coriáceas, discolores, pontuações translúcidas densas pouco visíveis a olho $\mathrm{nu} ; 47-50 \times 25-30 \mathrm{~mm}$; nervura principal impressa ou levemente sulcada na face adaxial, proeminente na abaxial; nervuras secundárias pouco visíveis, 4-7 pares; nervura marginal 2-5 $\mathrm{mm}$ do bordo, nervura intramarginal ausente; pecíolo 2-3 mm compr. Racemos "stenocalyx" reduzidos, em nós folhosos ou áfilos, 1-2 pares de flores, eixo 1-1,5 mm compr.; ferófilos elípticos ou ovados, 2-4 mm compr., ciliados; antopódio 15-28 mm compr.; prófilos lineares, não conados, 1-1,5 mm compr., ciliados, decíduos. Botões florais oblongos, 3-5 × 3-4 mm; cálice ocultando parcialmente o globo petalífero, lobos oblongos, $5 \times 1,5-2,5 \mathrm{~mm}$, iguais entre si, ciliados, reflexos após a antese; hipanto 8-costado longitudinalmente; ovário com 10 óvulos/lóculo. Frutos subglobosos, 8-costados longitudinalmente, 15-20 mm diâm., vermelhos quando maduros; sementes 1-2, até ca. de $10 \mathrm{~mm}$ diâm., testa membranácea.

Material examinado: PARAÍBA: Mataraca, Millennium Inorganic Chemicals LTDA, restinga arbustiva, 29.V.2009, fl. e fr., A.R. Lourenço 276 (JPB). RIO GRANDE DO NORTE: Mata Estrela, restinga arbustiva, 28.III.2006, fr., A.R. Lourenço 128 (JPB).

Encontrada em várias regiões e ambientes do Brasil. Abundante nas regiões litorâneas ocorre ocasionalmente na Floresta Atlântica (Souza et al. 2008). Na área de estudo foi encontrada na restinga arbustiva. Espécie amplamente cultivada pelos frutos comestíveis, comum em áreas antropizadas. Floresce e frutifica ao longo de todo o ano.

\subsection{Eugenia sp.}

Fig. 1f

Árvores ou arbustos de 4 a $15 \mathrm{~m}$ de altura, ramos jovens, pecíolos, nervura principal e face abaxial das folhas jovens pubescentes, face adaxial puberulenta, folhas adultas puberulentas ou glabrescentes, inflorescências e frutos vilosos ou velutinos, indumento gríseo-esbranquiçado ou castanho; tronco com casca externa castanha, esfoliando-se em placas rígidas. Folhas ovadas a elípticas, ápice agudo ou curto-acuminado, base arredondada a aguda, bordo revoluto nas folhas jovens, não revoluto nas adultas, cartáceas a 
coriáceas, discolores, brilhantes na face adaxial, opacas na abaxial, pontuações translúcidas pouco visíveis a olho nu na face adaxial, não visíveis na abaxial; 37-70 × 18-31 mm; nervura principal impressa a sulcada na face adaxial, proeminente na abaxial; nervuras secundárias visíveis na face abaxial das folhas jovens, pouco visíveis nas folhas adultas, 6-12 pares; nervura marginal 1-4 mm do bordo, nervura intramarginal ausente; pecíolo 4-5 mm compr. Racemos "stenocalyx" em nós folhosos basais, 2 flores, eixo $1 \mathrm{~mm}$ compr.; ferófilos elípticos a espatulados, 4-6 mm compr., ciliados; antopódio 20-30 mm compr.; prófilos lineares, não conados, 3-5 mm compr., ciliados, decíduos. Botões florais globosos, 10 mm diâm.; cálice não ocultando o globo petalífero, lobos curto-espatulados ou espatulados, 6-8 × 5-7 mm, desiguais, com dois maiores e dois menores, ciliados, não reflexos após a antese; hipanto não costado longitudinalmente; ovário com 14-15 óvulos/lóculo. Frutos globosos a subglobosos, não costados, 25-30 × 23-32 mm, amarelos quando maduros; semente 1, 15-20 mm de diâm., testa coriácea, fibrosa.

Material examinado: PARAIIBA: Mataraca, restinga arbórea, 22.XII.2004, fl., P.G. Gadelha Neto 1321 (JPB); 17.XII.2007, fl., P.G. Gadelha Neto 1981 (JPB); 30.IV.2009, fr., P.G. Gadelha Neto 2586 (JPB); 29.V.2009, fr., A.R. Lourenço 272 (JPB).

Material adicional examinado: PARAÍBA: João Pessoa, 9.I.1986, fl., bt., O.T. Moura 236 (JPB).

Conhecida até o momento somente para o estado da Paraíba, ocorrendo em ambientes de restinga e tabuleiro litorâneo. Em Mataraca foi encontrada na restinga arbórea. É afim de E. azuruensis O. Berg, principalmente pela morfologia dos botões florais, porém, difere-se desta pelas folhas e frutos. Estudos complementares estão em andamento para definição de um melhor posicionamento taxonômico da espécie. (A. R. L. de Lourenço, comunicação pessoal). Apresenta como principal característica os pedicelos longos, que se espessam durante a formação dos frutos para sustentá-los, estes caracteristicamente velutinos. Floresce e frutifica durante os meses de novembro e julho.

\section{Myrciaria O. Berg, Linnaea 27: 320. 1856.}

Arbustos ou árvores de pequeno porte, glabrescentes a pubescentes, indumento simples. Inflorescências fascículos (ramos bracteados reduzidos, de acordo com Landrum \& Kawasaki 1997), axilares, ferófilos e prófilos persistentes na antese, estes conados; flores tetrâmeras, pétalas brancas; cálice aberto no botão floral, ocultando ou não o globo petalífero; hipanto prolongado acima do ovário, circuncidado no ponto de junção com este, caindo juntamente com o cálice, como uma unidade, após a antese; ovário bilocular, 2 óvulos/ lóculo. Fruto bacídio, globoso, com cicatriz circular no ápice; sementes de testa coriácea ou fibrosa.

Com cerca de 30 espécies no Brasil (Sobral et al. 2012), a grande maioria na região sudeste, ocorre da América Central e Caribe até o norte da Argentina (Landrum \& Kawasaki 1997).

2.1 Myrciaria floribunda (H. West ex Willd.) O. Berg, Linnaea 27: 330. $1856 . \quad$ Fig. 1g-h

Arbustos ou arvoretas até $5 \mathrm{~m}$ de altura, glabros, exceto pelos ramos, folhas e pecíolos glabrescentes; tronco com casca desprendendose em placas rígidas. Folhas elípticas ou ovadolanceoladas, ápice longo acuminado, base cuneada ou arredondada, bordo não revoluto, cartáceas, discolores, brilhantes ou opacas na face adaxial, opacas na abaxial, pontuações translúcidas densas pouco visíveis a olho nu na face adaxial, visíveis na abaxial; $22-80 \times 8-36$ $\mathrm{mm}$; nervura principal impressa na face adaxial, proeminente na abaxial; nervuras secundárias 14-20 pares; nervura marginal 0,5 a $2 \mathrm{~mm}$ do bordo, nervura intramarginal ausente; pecíolo 2-6 mm compr. Fascículos axilares em nós folhosos basais, até 6 flores, eixo ca. $1 \mathrm{~mm}$ compr.; ferófilos arredondados, ca. de 0,5 mm compr., ciliados; antopódio 0,5-1 $\mathrm{mm}$ compr.; prófilos arredondados, até $1 \mathrm{~mm}$ compr., ciliados. Botões florais obcônicos a globosos, 2-2,5 × 2,5-3 mm; cálice não ocultando o globo petalífero, lobos arredondados, 1-1,5 mm diâm., ciliados. Frutos ca. de $8 \mathrm{~mm}$ diâm., negros quando maduros; semente 1, ca. de $7 \mathrm{~mm}$ de diâm.

Material examinado: PARAÍBA: Mataraca, Millennium Inorganic Chemicals LTDA, restinga arbustivoherbácea, 30.IX.2008, fl., bt., A.R. Lourenço 200 (JPB); fr., A.R. Lourenço 203 (JPB); fr., A.R. Lourenço 204 (JPB); 9.III.2009, fl., A.R. Lourenço 237 (JPB); fl., A.R. Lourenço 238 (JPB); A.R. Lourenço 248; restinga arbustiva, 17.XII.2007, fr., P.C. Gadelha Neto 2017 (JPB). RIO GRANDE DO NORTE: Baía Formosa, Mata Estrela, restinga arbustiva, 28.III.2006, fl., A.R. Lourenço 131 (JPB).

Ocorre desde o estado do Pará até o Rio Grande do Sul, na Amazônia, Caatinga, Cerrado e Mata Atlântica. Foi encontrada nas restingas 
de Mataraca e na Mata Estrela principalmente na restinga arbustiva e na transição desta para a restinga herbácea. A espécie distingue-se das demais pelo conjunto das folhas de ápice longoacuminado com inflorescências de eixo reduzido, fazendo com que os frutos tenham uma aparência ramiflora. Floresce de março a setembro, frutifica de setembro a dezembro.

2.2 Myrciaria tenella (DC.) O. Berg, Linnaea 27: 328. 1856.

Arbustos ou arvoretas até $4 \mathrm{~m}$ de altura, ramos novos, face abaxial das folhas, pecíolos, inflorescências e flores pubescentes ou puberulentos, tricomas acinzentados a castanhos; tronco com casca externa desprendendo-se em placas rígidas, caule castanho. Folhas elípticas, ápice agudo, base aguda ou cuneada, bordo revoluto, cartáceas, discolores, pontuações translúcidas não visíveis a olho nu na face adaxial, visíveis na abaxial; $10-29 \times 5-10 \mathrm{~mm}$; nervura principal sulcada na face adaxial, proeminente na abaxial; nervuras secundárias 8-12 pares, inconspícuas; nervura marginal ca. $0,5 \mathrm{~mm}$ do bordo, nervura intramarginal ausente; pecíolo até $1 \mathrm{~mm}$ compr. Fascículos axilares em nós folhosos basais, até 4 flores, eixo menor que $1 \mathrm{~mm}$ compr.; ferófilos ovados ou arredondados, até $0,5 \mathrm{~mm}$ compr., ciliados; antopódio ca. 0,5 mm compr.; prófilos arredondados ou arredondado-elípticos, ca. $0,5 \mathrm{~mm}$ compr., ciliados. Botões florais subglobosos, 1-1,5 mm diâm.; cálice ocultando o globo petalífero, lobos oblongos, ca. 1,5 mm compr., ciliados. Frutos ca. de $7 \mathrm{~mm}$ diâm., negros quando maduros; semente 1, ca. de $6 \mathrm{~mm}$ diâm. Material examinado: RIO GRANDE DO NORTE: Mata Estrela, 28.III.2006, fl., A.R. Lourenço 134 (JPB); A. R. Lourenço 140 (JPB).

Distribuida na América Central, Venezuela, Argentina, Uruguai e, no Brasil, desde a região norte ao Rio Grande do Sul, na Amazônia, Caatinga, Cerrado e Mata Atlântica. Foi encontrada na Mata Estrela, na fisionomia arbustiva. Espécie de difícil visualização no campo, principalmente devido às inflorescências inconspícuas e localizadas na face inferior das axilas foliares.

\section{Subtribo Myrciinae (Calyptranthes e Myrcia)}

Embrião mircioide, com cotilédones folhosos e finos dobrados em uma estrutura circundada por um longo hipocótilo.
3. Calyptranthes Sw., Prodr. 5: 79. 1788.

Arbustos ou árvores de pequeno a médio porte, indumento dibraquiado. Inflorescências tirsoides axilares terminais; ferófilos e prófilos livres entre si. Flores com $0-5$ pétalas reduzidas; cálice fechado no botão floral, este apiculado, abrindo-se na antese por meio de uma caliptra que pode permanecer presa por uma pequena porção de tecido até a formação do fruto; ovário 2-3 locular, dois óvulos por lóculo, placentação basal. Fruto bacáceo coroado por uma cicatriz circular, 1-3 sementes.

Ocorre desde o México e Caribe até o norte da Argentina, com provavelmente mais de 100 espécies (Mc Vaugh 1968; Barroso \& Peron 1994), 69 citadas recentemente na lista do Brasil (Sobral et al. 2012). $\mathrm{Na}$ área de estudo está representado por uma única espécie, Calyptranthes brasiliensis Spreng., encontrada na restinga arbórea e na formação ripária arbustiva das restingas de Mataraca e Mata Estrela.

3. 1 Calyptranthes brasiliensis Spreng., Syst. Veg. (ed. 16) 2: 499. 1825.

Fig. 2a-d

Arbustos ou árvores até $8 \mathrm{~m}$ de altura, ramificados dicotomicamente, ramos jovens, pecíolos, e inflorescências pubescentes, glabros na maturidade, face adaxial e abaxial das folhas puberulentas, pubescentes perto da nervura principal na face abaxial, indumento brúneo-ferrugíneo; tronco com casca externa desprendendo-se em placas rígidas. Folhas elípticas ou elíptico-oblongas, ápice curto-acuminado ou agudo, base cuneada ou arredondada, bordo ligeiramente revoluto, coriáceas, discolores, opacas, pontuações translúcidas densas não visíveis a olho nu na face adaxial, visíveis na abaxial; 110-167 × 43-73 mm; nervura principal sulcada na face adaxial, proeminente na abaxial; nervuras secundárias 15-20 pares; nervura marginal 2-4 $\mathrm{mm}$ do bordo, nervura intramarginal 0,5-1 $\mathrm{mm}$ do bordo; pecíolo 6-12 $\mathrm{mm}$ compr. Tirsóides 1-2 axilares em nós folhosos, 52-105 mm compr., 2-4 pares de ramificações laterais opostas, hipopódio 35-50 mm compr.; ferófilos arredondados a ovados, 1-2 mm compr., ciliados; antopódio 1-2 mm compr.; prófilos triangulares ou triangulo-lineares, ca. $1 \mathrm{~mm}$ compr., ciliados, decíduos. Botões florais arredondados ou obcônicos, $3 \times 2-2,5 \mathrm{~mm}$; hipanto prolongado ca. de $2 \mathrm{~mm}$ acima do ovário; ovário bilocular. 


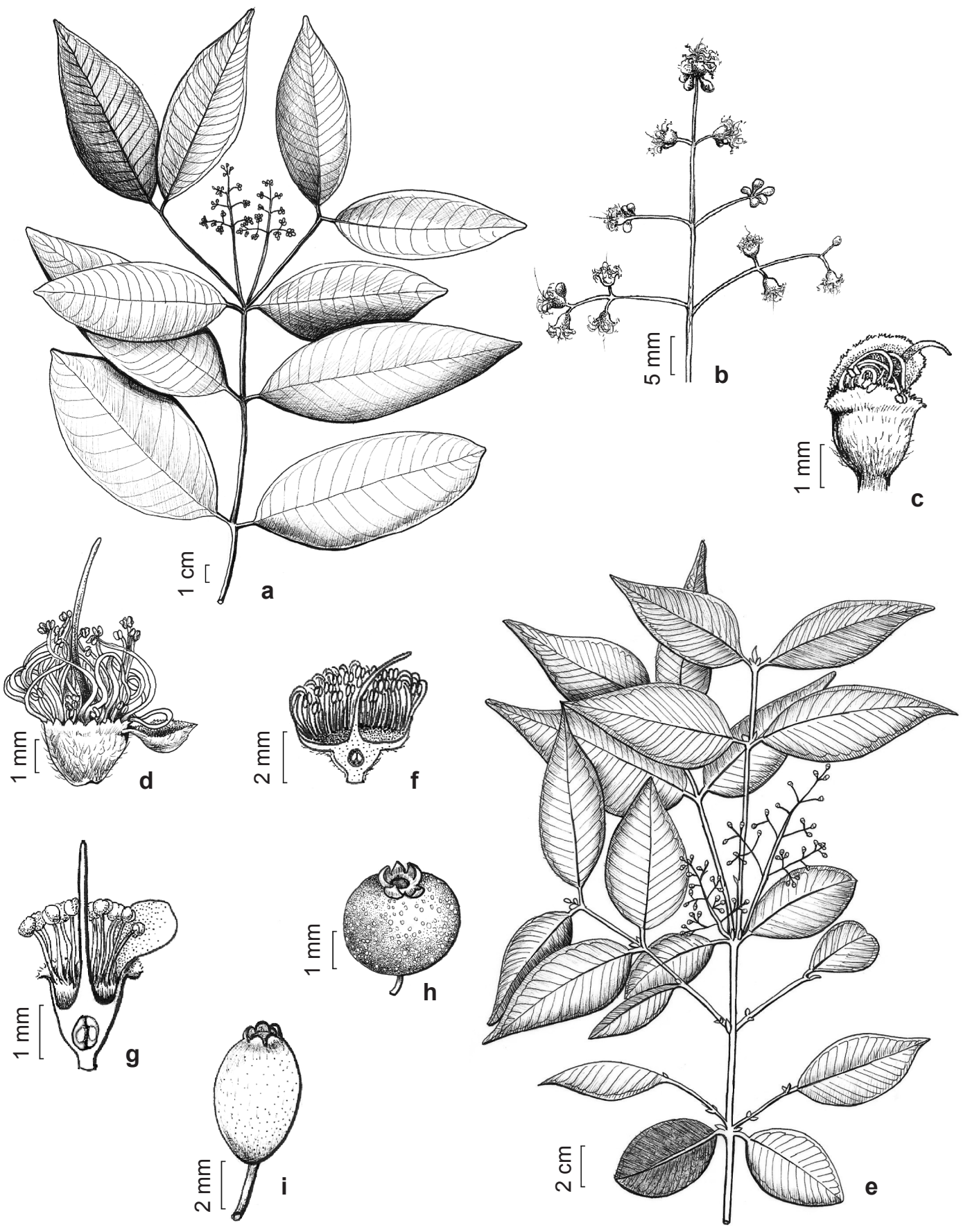

Figura 2 - Subtribo Myrciinae - a-d. Calyptranthes brasiliensis - a. ramo com inflorescências; b. inflorescência tirsóide; c. botão floral abrindo-se por uma caliptra; d. flor aberta. e-f. Myrcia bergiana - e. ramo com inflorescências; f. seção longitudinal da flor, mostrando o hipanto não prolongado. g-h. Myrcia multiflora - g. seção longitudinal da flor, mostrando o hipanto prolongado; h. fruto subgloboso. i. Myrcia sylvatica - i. fruto elipsoide. (a-d Gadelha Neto 1982; e-f Lourenço 236; g-h Lourenço 207; i Lourenço 211).

Figure 2 - Subtribe Myrciinae - a-d. Calyptranthes brasiliensis - a. stem with inflorescences; b. thyrsoid inflorescence; c. floral bud opening by a calyptra; d. opened flower. e-f. Myrcia bergiana - e. stem with inflorescences; f. longitudinal section of the flower, showing the hypanthium not prolonged. g-h. Myrcia multiflora - g. longitudinal section of the flower, showing the prolonged hypanthium; h. fruit subglobose. i. Myrcia sylvatica - i. fruit ellipsoid. (a-d Gadelha Neto 1982; e-f Lourenço 236; g-h Lourenço 207; i Lourenço 211). 
Frutos globosos a subglobosos, até $7 \mathrm{~mm}$ diâm., negros quando maduros; sementes $2-3$, ca. de 5 mm diâm., testa cartácea, maleável.

Material examinado: PARAÍBA: Mataraca, Millennium Inorganic Chemicals LDTA, formação ripária arbustiva, 25.III.2009, fr., A.R. Lourenço 253 (JPB); fr., A.R. Lourenço 257 (JPB); 17.XII.2007, fl., P.C. Gadelha Neto 1982 (JPB). RIO GRANDE DO NORTE: Mata Estrela, restinga arbórea, 19.VII.2010, fr., A.R. Lourenço 296 (JPB); fr., A.R. Lourenço 301 (JPB).

Amplamente distribuída, com duas principais áreas de ocorrência, a Mata Atlântica e a Amazônia, com poucos representantes na Caatinga e Cerrado. $\mathrm{Na}$ área de estudo ocorre na restinga arbórea e na formação ripária arbustiva. Distingue-se das outras espécies pelas ramificações dicotômicas nas porções finais dos ramos, botões abrindo-se em forma de caliptra e pelos tricomas dibraquiados, de coloração ferrugínea. É afim da espécie $C$. dardanoi Mattos, cuja diferenciação está sendo alvo de um estudo atual mais aprofundado por parte da primeira autora do presente trabalho. Floresce de dezembro a abril, frutifica de março a julho.

4. Myrcia DC. ex. Guill., Dict. Class. Hist. Nat. 11: 401.1827.

Subarbustos ou árvores, glabras a tomentosas, indumento simples. Inflorescências tirsoides ou panículas axilares ou subterminais, prófilos e ferófilos decíduos na antese. Flores pentâmeras, pétalas brancas ou com aspecto ferrugíneo devido ao indumento; cálice aberto no botão floral, com lobos iguais ou desiguais, ocultando ou não o globo petalífero; hipanto prolongado ou não acima do ovário; ovário 2-3 locular, dois óvulos/lóculo. Fruto bacáceo, globoso ou elipsóide, com cálice persistente; sementes 1-4; testa cartilaginosa, membranácea ou fibrosa.

Distribui-se desde o México, Antilhas, Guianas, Peru, até a Argentina, Paraguai e Uruguai (Landrum \& Kawasaki 1997; Soares-Silva 2000), tendo uma ampla distribuição no Brasil. Mc Vaugh (1969) estimou cerca de 300 espécies para o gênero, enquanto Mabberley (1997) estimou não mais que 250 espécies. No Brasil ocorrem ca. de 200 espécies (Sobral et al. 2012).

\subsection{Myrcia bergiana O. Berg, Fl. bras. 14(1): 194.} 1857.

Fig. 2e-f

Arbustos ou árvores até $10 \mathrm{~m}$ de altura, ramos, folhas, pecíolo e inflorescências tomentosos, brúneo- avermelhados nos mais jovens, gríseo-esbranquiçados quando maduros, face abaxial das folhas denso-tomentosas nas mais jovens, tomentulosas nas adultas, face adaxial tomentulosa ou glabra; tronco com casca externa lisa ou áspera, desprendendose em lâminas, caule gríseo-esbranquiçado ou levemente avermelhado. Folhas ovadolanceoladas, ápice longo a médio acuminado, base arredondada ou cuneada, bordo ligeiramente revoluto, coriáceas, discolores, brilhantes na face adaxial, opacas na abaxial, pontuações translúcidas densas não visíveis a olho nu; 85-144 × 37-50 mm; nervura principal sulcada na face adaxial, proeminente na abaxial; nervuras secundárias, 15-20 pares; nervura marginal 1-2 $\mathrm{mm}$ do bordo, nervura intramarginal ausente; pecíolo 5-7 mm compr., canaliculado. Tirsoides 1-2 axilares em nós folhosos basais ou terminais, 35-78 mm compr., 2-4 pares de ramificações laterais opostas, hipopódio 10-24 mm compr., ferófilos triangulares a triângulo-lineares, 2-4 mm compr., ciliados; prófilos triangulares, não conados, 1-2 mm compr., ciliados. Botões florais obcônicos, 3-4 mm compr.; cálice ocultando parcialmente o globo petalífero, lobos deltóides, dois com $2 \times 2 \mathrm{~mm}$, três com $2 \times 3 \mathrm{~mm}$, ciliados; hipanto não prolongado acima do ovário; ovário bilocular. Frutos globosos ou subglobosos, até 8 mm diâm., amarelos quando maduros; sementes 2, até ca. 6 mm diâm., testa membranácea.

Material examinado: PARAÍBA: Mataraca, Millennium Inorganic Chemicals LTDA, restinga arbórea, 4.X.2007, fr., I.B. Lima 803 (JPB); 30.IX.2008, fr., A.R. Lourenço 201 (JPB); fr., A.R. Lourenço 202 (JPB); 9.III.2009, fl., A.R. Lourenço 236 (JPB); ecótono savana-restinga, 25.III.2009, fl., A.R. Lourenço 256 (JPB); restinga arbustiva, 29.V.2009, fl. e fr., A.R. Lourenço 264 (JPB); fl. e fr., A.R. Lourenço 265 (JPB); fl., A.R. Lourenço 266 (JPB); fr., A.R. Lourenço 267 (JPB). RIO GRANDE DO NORTE: Baía Formosa, Mata Estrela, restinga arbórea, 4.VIII.2004, fl., A.R. Lourenço 23 (JPB).

Encontrada no Rio Grande do Norte, Paraíba, Pernambuco e Bahia, na Caatinga e Mata Atlântica. $\mathrm{Na}$ área de estudo está presente nas restingas arbustiva e arbórea e no ecótono savanarestinga. Reconhecida facilmente no campo pela face abaxial das folhas apresentando indumento de coloração ferrugínea, de toque aveludado, e pelas pétalas também ferrugíneas devido a este indumento. Floresce de fevereiro a maio, frutifica de abril a setembro. 
4.2 Myrcia guianensis (Aubl.) DC., Prodr. 3: 245. 1828.

Arvoreta ou árvore até 6 metros de altura, ramos, pecíolos, nervura principal das folhas na face abaxial e inflorescências glabrescentes, tricomas esbranquiçados, acinzentados ou brúneo-pardacentos; tronco com casca externa lisa, acinzentada, esfoliante em lâminas finas. Folhas elípticas, ovadas ou orbiculares, ápice agudo, curto-acuminado, arredondado ou obtuso, ligeiramente retuso, base cuneada ou arredondada, bordo revoluto ou ligeiramente revoluto, cartáceas a coriáceas, discolores, brilhantes ou opacas na face adaxial, opacas na abaxial, pontuações translúcidas pouco visíveis a olho nu na face adaxial, visíveis na abaxial; 37-95 × 25-42 mm; nervura principal impressa ou proeminente na face adaxial, proeminente na abaxial; nervuras secundárias 6-12 pares; nervura marginal 1-2 mm do bordo, nervura intramarginal ausente; pecíolo 4-7 mm compr., não canaliculado. Tirsoides axilares em nós folhosos terminais, $45-90 \mathrm{~mm}$ compr., 3-4 pares de ramificações laterais opostas, o primeiro podendo ser sub-oposto; hipopódio 25-55 mm compr.; ferófilos lineares, até $3 \mathrm{~mm}$ compr., levemente ciliados; prófilos lineares, não conados, até $1 \mathrm{~mm}$ compr., levemente ciliados. Botões florais obcônicos, 3-4 mm compr.; cálice não ocultando o globo petalífero, lobos crassos, arredondado-truncados, dois maiores com $1 \times$ $2 \mathrm{~mm}$, três menores com $1 \times 1,5 \mathrm{~mm}$, ciliados, estrigosos internamente; hipanto prolongado ca. $1 \mathrm{~mm}$ acima do ovário; ovário trilocular. Frutos globosos, até $10 \mathrm{~mm}$ diâm., vináceos a negros quando maduros; semente 1, ca. de 6 mm diâm., testa cartácea.

Material examinado: PARAÍBA: Mataraca, Millennium Inorganic Chemicals LTDA, restinga arbustiva, 4.X.2007, fl., I.B. Lima 802 (JPB); 27.VIII.2008, fl., fr., A.R. Lourenço 190 (JPB); fr., A.R. Lourenço 194 (JPB); 20.I.2009, fl., A.R. Lourenço 212 (JPB); 25.III.2009, fr., A.R. Lourenço 259 (JPB); 29.V.2009, fl. e fr., $A$ R. Lourenço 265 (JPB); fl., A.R. Lourenço 266 (JPB). RIO GRANDE DO NORTE: Baía Formosa, Mata Estrela, restinga arbustiva, 4.VIII.2004, fr., A.R. Lourenço 41 (JPB); restinga arbórea, 21.I.2009, fl., A.R. Lourenço 218 (JPB).

Ocorre no Panamá, Colômbia, Venezuela, Trinidad-Tobago, Guiana, Suriname, Peru e Bolívia, sendo amplamente distribuída no Brasil na Amazônia, Caatinga, Cerrado e Mata Atlântica.
$\mathrm{Na}$ área de estudo foi encontrada nas restingas arbustiva e arbórea.

É uma das espécies de distribuição mais ampla dentro do gênero, e a mais variável morfologicamente da América do Sul (Holst et. al. 2005). Floresce de janeiro a maio e agosto, frutifica de março a maio e agosto.

4.3 Myrcia lundiana Kiaersk., Enum. Myrt. Bras., 78. 1893.

Arvoretas até $4 \mathrm{~m}$ de altura, glabras, exceto pelos ramos jovens e inflorescências glabrescentes, com indumento avermelhado; tronco com casca externa esfoliando-se em placas, caule avermelhado. Folhas elípticas ou ovado-elípticas, ápice acuminado ou médio acuminado, base arredondada ou cuneada, bordo ligeiramente revoluto, coriáceas, discolores, ligeiramente brilhantes na face adaxial, opacas na abaxial, pontuações translúcidas densas não visíveis a olho nu; 35-60 × 20-30 mm; nervura principal sulcada na face adaxial, proeminente na abaxial; nervuras secundárias 10-12 pares, pouco visíveis; nervura marginal $1-2 \mathrm{~mm}$ do bordo, nervura intramarginal até 0,5 do bordo; pecíolo 4-6 mm compr., não canaliculado. Panículas terminais ou axilares em nós folhosos, 65-88 $\mathrm{mm}$ compr., 3-5 pares de ramificações laterais alternas, o primeiro podendo ser sub-oposto; hipopódio $35 \mathrm{~mm}$ compr.; ferófilos ovados, 1-2 mm compr., ciliados; prófilos ovados, não conados, 0.5-1 mm compr., ciliados. Botões florais obcônicos, ca. $2 \mathrm{~mm}$ compr.; cálice ocultando parcialmente o globo petalífero, lobos arredondados, ligeiramente desiguais, ciliados; hipanto prolongado ca. $0,5 \mathrm{~mm}$ acima do ovário; ovário bilocular. Frutos não observados; sementes não observadas.

Material examinado: RIO GRANDE DO NORTE: Mata Estrela, topo de duna, restinga herbácea, 29.III.2006, fl., A.R. Lourenço 174 (JPB).

Material adicional examinado: RIO GRANDE DO NORTE: Natal, Parque das Dunas, 11.XI.1980, fl., 234 (RB).

Ocorre no Rio Grande do Norte, Sergipe, Rio de Janeiro e Espírito Santo, na Mata Atlântica. $\mathrm{Na}$ área de estudo foi encontrada na Mata Estrela, em topo de duna, restinga herbácea. A espécie apresenta pouca representatividade nos herbários visitados, acreditando-se que seja rara. Floresce de novembro a março. 
4.4 Myrcia multiflora (Lam.) DC., Prodr. 3:244. 1828.

Fig. $2 \mathrm{~g}-\mathrm{h}$

Arbustos ou arvoretas de aprox. $5 \mathrm{~m}$ de altura, ramos jovens hirtos, pecíolos puberulentos, face abaxial das folhas e inflorescências puberulentas a glabras, tricomas esbranquiçados a pardacentos; tronco com casca externa esfoliandose em lâminas papiráceas, caule avermelhado ou acinzentado. Folhas elípticas ou ovadoelípticas, ápice leve a medianamente acuminado ou obtuso-curto-acuminado, base cuneada, raro arredondada, bordo revoluto, cartáceas a coriáceas, discolores, opacas em ambas as faces, pontuações translúcidas esparsas não visíveis a olho nu; 33-52 × 12-30 mm; nervura principal impressa ou sulcada na face adaxial, proeminente na abaxial; nervuras secundárias 8-12 pares, visíveis na face abaxial, pouco visíveis na adaxial; nervura marginal $0,5-2 \mathrm{~mm}$ do bordo, nervura intramarginal ausente; pecíolo 2-3 $\mathrm{mm}$ compr., não canaliculado. Panículas nas axilas de ferófilos, 20-40 mm compr., 2-4 pares de ramificações laterais alternas, o primeiro par podendo ser oposto; hipopódio 10-20 mm compr.; ferófilos ovados, ca. de $2 \mathrm{~mm}$ compr., ciliados; prófilos arredondados, não conados,ca. de $1 \mathrm{~mm}$ compr., ciliados. Botões florais obcônicos, $2-3 \mathrm{~mm}$ compr.; cálice não ocultando o globo petalífero, lobos triangulares, 3 com 1-1,5 × 1,5-2 mm, de ápice truncado, e 2 com ápice agudo, ciliados; hipanto prolongado ca. de $0,5 \mathrm{~mm}$ acima do ovário; ovário bilocular. Frutos globosos, até 6 mm diâm., negros quando maduros; sementes 1-3, 3-5 mm diâm., testa fibrosa.

Material examinado: PARAÍBA: Mataraca, Millennium Inorganic Chemicals LTDA, mata de restinga, 30.IX.2008, fl., A.R. Lourenço 207 (JPB); mata de restinga, 9.III.2009, fr., A.R. Lourenço 246 (JPB); fr., A.R. Lourenço 247 (JPB); mata de restinga, 25.III.2009, fr., A.R. Lourenço 258 (JPB); mata de restinga, 29.V.2009, fr., A.R. Lourenço 268 (JPB); restinga arbustiva, fr., A.R. Lourenço 271 (JPB); 17.XII.2007, fl., P.C. Gadelha Neto 2015 (JPB). RIO GRANDE DO NORTE: Baía Formosa, Mata Estrela, restinga arbórea, 5.II.2006, fl., A.R. Lourenço 109 (JPB).

Amplamente distribuída do norte da América do Sul ao sul Brasil. $\mathrm{Na}$ área de estudo, a espécie foi encontrada nas fisionomias de restinga arbórea e restinga arbustiva. A espécie apresenta uma grande variação morfológica, principalmente nas folhas e no hábito, fato mencionado por Legrand \& Klein (1969) como causa da grande lista de sinônimos existentes para a espécie. Floresce predominantemente de fevereiro a março, frutifica de março a setembro.

4.5 Myrcia splendens (Sw.) DC., Prodr. 3: 244. 1828.

Arvoretas ou arbustos até $5 \mathrm{~m}$ de altura, ramos jovens, pecíolos, inflorescências e frutos tomentosos, face abaxial das folhas tomentulosa, face adaxial glabra, indumento gríseo ou pardacento; tronco com casca externa esfoliandose em placas rígidas. Folhas elípticas, elípticoalongadas ou ovado-elípticas, ápice acuminado ou obtuso-curto-acuminado, base cuneada, bordo revoluto, coriáceas, discolores, brilhantes na face adaxial, opacas na abaxial, pontuações translúcidas densas não visíveis a olho nu; 70-145 × 35-50 mm; nervura principal sulcada na face adaxial, proeminente na abaxial; nervuras secundárias 15-22 pares; nervura marginal 0,5-2 $\mathrm{mm}$ do bordo, nervura intramarginal ausente; pecíolo 3-6 mm compr., levemente canaliculado. Tirsoides axilares em nós folhosos basais ou terminais, 55-135 mm compr., 4-5 pares de ramificações laterais opostas; hipopódio 20-40 mm compr.; ferófilos não observados; prófilos elíptico-lineares, não conados, ca. $2 \mathrm{~mm}$ compr., ciliados. Botões florais globosos, 3-4 mm compr., cálice não ocultando o globo petalífero, lobos arredondados ou deltóides, ligeiramente desiguais, $1-2 \times 1-2 \mathrm{~mm}$, ciliados; hipanto não prolongado acima do ovário; ovário bilocular. Frutos elipsoides, 8-10 × 4-6 mm, negros quando maduros; semente 1 , até $6 \mathrm{~mm}$ compr., testa membranácea.

Myrcia splendens é amplamente distribuída, desde o leste do México, e Antilhas, até o sul do Brasil. Na área de estudo ocorre na restinga arbórea. Espécie frequente nas coleções brasileiras, porém, identificada como M. fallax DC. Mc Vaugh $(1958,1963)$ já havia discorrido extensamente sobre este complexo, e recentemente $M$. fallax foi sinonimizada em $M$. splendens por Govaerts et al. (2008). Floresce de novembro a janeiro, frutifica de março a maio.

Material examinado: RIO GRANDE DO NORTE: Baía Formosa, Mata Estrela, restinga arbórea, 29.III.2006, fl., A.R. Lourenço 152 (JPB).

Material adicional examinado: BAHIA: Morro do Chapéu, 5.V.2007, fr., Pastore \& Cortes 1932 (HUEFS). 
4.6 Myrcia sylvatica (G. Mey.) DC., Prodr. 3: 244. 1828.

Fig. $2 \mathrm{i}$

Arbustos ou árvores até $8 \mathrm{~m}$ de altura, ramos jovens vilosos, axilas foliares circundadas por brácteas lineares castanhas, face abaxial das folhas tomentulosas a glabras, com nervura principal tomentosa, face adaxial glabra, inflorescências e botões tomentosos a pubescentes, indumento gríseo; tronco com casca externa acinzentada, esfoliando-se em lâminas finas. Folhas elíptico-lanceoladas ou ovado-lanceoladas, ápice longo-acuminado, base cuneada ou arredondada, bordo revoluto, cartáceas a coriáceas, discolores, opacas ou brilhantes na face adaxial, opacas na abaxial, pontuações translúcidas não visíveis a olho $\mathrm{nu} ; 40-65 \times 15-24 \mathrm{~mm}$; nervura principal sulcada na face adaxial, proeminente na abaxial; nervuras secundárias inconspícuas, 14-19 pares; nervura marginal $0,5-1 \mathrm{~mm}$ do bordo, nervura intramarginal ausente; pecíolo 1,5-2 $\mathrm{mm}$ compr., não canaliculado. Tirsoides axilares em nós folhosos terminais, $40-55 \mathrm{~mm}$ compr., 3-5 pares de ramificações laterais opostas; hipopódio 10-15 mm compr.; ferófilos lineares, ca. de $2 \mathrm{~mm}$ compr., ciliados; prófilos lineares, não conados, ca. de $1 \mathrm{~mm}$ compr., ciliados. Botões florais obcônicos, ca. 2 mm compr.; cálice não ocultando o globo petalífero, lobos semi-circulares, ligeiramente desiguais, três maiores com ápice arredondado ou truncado, dois menores com ápice apiculado, ca. $1 \mathrm{~mm}$; hipanto não prolongado acima do ovário; ovário bilocular. Frutos elipsóides, 8-9 × 5-6 mm, amarelo-alaranjados quando maduros; semente 1, aprox. $7 \times 4 \mathrm{~mm}$, testa fina, porém rígida.

Material examinado: PARAÍBA: Mataraca, Millennium Inorganic Chemicals LTDA, mata de restinga, 17.XII.2007, fl., P.C. Gadelha Neto 2006 (JPB); restinga arbustiva, 17.VI.2008, fr., P.C. Gadelha Neto 2371 (JPB); ecótono savana-restinga, 20.I.2009, fl., A.R. Lourenço 211 (JPB); 9.III.2009, fl. e fr., A.R. Lourenço 234 (JPB).

Amplamente distribuída desde a América Central, na Costa Rica e Panamá, à América do Sul, das Guianas até o Paraguai. No Brasil, há registros para as regiões norte, centro-oeste e nordeste, nos domínios da Mata Atlântica, Amazônia e Cerrado. Na área de estudo foi encontrada na restinga arbustiva, restinga arbórea e no ecótono savana-restinga.
É afim de Myrcia splendens, sendo identificada como tal em alguns herbários consultados. Difere-se desta, principalmente pela forma do botão floral e dos lobos do cálice.

4.7 Myrcia tomentosa (Aubl.) DC., Prodr. 3: 245. 1828.

Arbusto ca. $2 \mathrm{~m}$ de altura, ramos jovens, pecíolos, inflorescências e frutos gríseocanescentes a tomentosos, folhas pubescentes a puberulentas, nervura principal tomentosa a pubescente em ambas as faces; tronco com casca externa acinzentada, esfoliante em lâminas finas, caule avermelhado. Folhas obovadas ou elípticas, ápice curto-acuminado ou agudo, base atenuada ou cuneada, bordo levemente revoluto, cartáceas a coriáceas, discolores, opacas em ambas as faces, pontuações translúcidas não visíveis a olho nu na face adaxial, visíveis na abaxial; 50-150 × 30-45 $\mathrm{mm}$; nervura principal impressa ou sulcada na face adaxial, proeminente na abaxial; nervuras secundárias 8-12 pares; nervura marginal $2-5 \mathrm{~mm}$ do bordo, nervura intramarginal 1-2 $\mathrm{mm}$ do bordo; pecíolo 4-6 mm compr., levemente canaliculado. Tirsoides axilares em nós folhosos basais, 40-60 mm compr., 3-4 pares de ramificações laterais opostas; hipopódio 13-18 mm compr.; ferófilos lineares, 2-3 $\mathrm{mm}$ compr., ciliados; prófilos arredondados, não conados, $0,5-1 \mathrm{~mm}$ compr., ciliados. Botões florais piriformes, 2-3 mm compr.; cálice ocultando parcialmente o globo petalífero, lobos desiguais, três maiores rombóides, dois menores deltoides, 1-2 × 1-2 mm, ciliados; hipanto prolongado ca. de $1 \mathrm{~mm}$ acima do ovário; ovário bilocular. Frutos globosos, 5-7 mm diâm., alaranjados quando maduros; semente 1-2, ca. 4 mm diâm., testa cartácea.

Material examinado: PARAÍBA: Mataraca, Millennium Inorganic Chemicals LTDA, ecótono savana-restinga, 6.III.2009, fr., A.R. Lourenço 251 (JPB). RIO GRANDE DO NORTE: Baía Formosa, Mata Estrela, restinga arbustiva, 22.I.2009, fl., A.R. Lourenço 219 (JPB).

Material adicional examinado: PARAIIBA: Mamanguape, Reserva Biológica Guaribas, mata de tabuleiro, 12.XII.2001, bt., fl., Camarotti 76 (JPB); 13.XII.1998, fl., M.S. Pereira 120 (JPB); 23.II.2001, fr., M.S. Pereira 283 (JPB).

Amplamente distribuída desde o Panamá, Trinidad e Tobago, Venezuela, Guianas, até o Brasil, ocorrendo no Nordeste, Centro-Oeste, Sudeste e Sul, alcançando a Argentina e o Paraguai. $\mathrm{Na}$ área de estudo ocorre no ecótono savanarestinga e na restinga arbustiva. 
Espécie característica pelos frutos cor-delaranja quando maduros. Floresce em dezembro, frutifica em fevereiro e março.

\section{Subtribo Myrtinae (Campomanesia e Psidium)}

Embrião mirtóide, com cotilédones relativamente pequenos, menores que o hipocótilo, este geralmente enrolado, o embrião inteiro em forma de "c" ou espiral; testa da semente dura, operculada, ou membranácea sem opérculo.

5. Campomanesia Ruiz \& Pav., Fl. Peruv. Prodr.: 72, pl. 13. 1794.

Arbustos ou árvores, glabros a pubescentes, indumento simples. Folhas com nervura marginal não evidente. Inflorescências dicásios simples ou compostos ou racemos reduzidos, prófilos e ferófilos persistentes ou decíduos na antese. Flores pentâmeras, pétalas brancas; cálice aberto no botão floral, com lobos iguais entre si; hipanto prolongado acima do ovário; ovário 5-19 locular (podendo variar no mesmo indivíduo) com paredes fortemente glandulares, até 12 óvulos/lóculo, vários deles abortando. Fruto campomanesioídeo, globoso ou ovado, com cálice persistente; sementes $1-4$; ; testa membranácea.

Distribui-se do norte da Argentina até Trinidad, e da costa do Brasil até os Andes ou Peru, Equador e Colômbia. (Landrum 1986). Landrum e Kawasaki (1997) reconheceram cerca de 30 espécies para a América do Sul, porém, para o Brasil são citadas 31 espécies (Sobral et al. 2012).

\subsection{Campomanesia aromatica Ž(Aubl.) Griseb.,} Fl. Brit. W. I.: 242. $1860 . \quad$ Fig. 3a-b

Arbustos de aprox. $2 \mathrm{~m}$ de altura, ramos jovens, folhas, pecíolos, inflorescências, flores e frutos pubescentes, glabros na maturidade, tricomas esbranquiçados a castanhos; tronco com casca externa acinzentada, de aspecto rugoso. Folhas elíptico-lanceoladas, elípticas, obovadas, ovadas ou oblongo-lanceoladas, ápice longo acuminado ou agudo, base cuneada, raro arredondada ou obtusa, membranáceas a cartáceas, discolores, brilhantes ou opacas na face adaxial, opacas na abaxial, pontuações translúcidas densas não visíveis a olho $\mathrm{nu}$; 60-140 × 20-48 mm; nervura principal sulcada na face adaxial, proeminente na abaxial; nervuras secundárias 6-10 pares; pecíolo 4-10 mm compr., canaliculado. Racemos "stenocalyx", bastante reduzidos a uma ou duas flores, axilares em nós folhosos basais, hipopódio ca. de $1 \mathrm{~mm}$ compr.; ferófilos espatulados, 3-8 mm compr., ciliados; antopódio 7-25 mm compr.; prófilos lineares, nãoconados, até $5 \mathrm{~mm}$ compr., ciliados, persistentes, às vezes afastados ca. de $5 \mathrm{~mm}$ da flor. Botões florais globosos a obcônicos, 3-4 mm diâm., cálice ocultando parcialmente o globo petalífero; lobos do cálice triangulares, 2-3 × 1,5-2 mm, ciliados; hipanto prolongado ca. de $1 \mathrm{~mm}$ acima do ovário; 10-12 óvulos/lóculo. Frutos globosos, até 10 mm diâm., vináceos ou negros quando maduros; sementes 1-2, 5-6 mm compr.

Material examinado: PARAÍBA: Mataraca, Millennium Inorganic Chemicals LTDA, restinga arbórea, 29.I.2008, fl., I.B. Lima 874 (JPB); 9.III.2009, fl. e fr., A.R. Lourenço 229 (JPB); fl., A.R. Lourenço 230 (JPB); restinga arbustiva, 25.III.2009, fr., A.R. Lourenço 252 (JPB); fr., A.R. Lourenço 254 (JPB); fl. e fr., A.R. Lourenço 255 (JPB).

Apresenta distribuição disjunta em Trinidad, Bolívia e Brasil, onde ocorre nos estados de Macapá e Pará na região norte, Maranhão, Piauí, Ceará, Rio Grande do Norte, Paraíba, Pernambuco, Sergipe e Bahia no nordeste, nos domínios da Amazônia, Caatinga e Mata Atlântica. Na área de estudo foi encontrada na restinga arbustiva e na restinga arbórea. A espécie apresenta lobos do cálice caracteristicamente estreitos nos frutos e número de lóculos variável por flor. Floresce de janeiro a março, frutifica em março.

\subsection{Campomanesia dichotoma (O. Berg) Mattos,} Loefgrenia 26: 28. 1967.

Fig. 3c

Arbustos ou árvores até $10 \mathrm{~m}$ de altura; ramos jovens, pecíolos, nervuras principais e secundárias das folhas densamente pubescentes a glabrescentes, inflorescências pubescentes, faces abaxial e adaxial das folhas pubérulas a glabras, tricomas castanhos a esbranquiçados; tronco com casca externa acinzentada, esfoliando-se em lâminas. Folhas orbiculares, ovadas ou elípticas, ápice agudo ou obtuso, às vezes curto-acuminado, base cuneada ou arredondada, raro subcordada, cartáceas a coriáceas, discolores, opacas em ambas as faces, pontuações translúcidas não visíveis a olho nu; 52-95 × 35-65 mm; nervura principal impressa ou sulcada na face adaxial, proeminente na abaxial; nervuras secundárias 5-6 pares; pecíolo 6-13 mm compr. Dicásios axilares em nós folhosos basais, hipopódio 3-4 mm compr., 3-7 flores, ferófilos e prófilos não observados. Botões florais globosos, 6-7 mm diâm.; cálice ocultando parcialmente o globo petalífero, lobos triangulares, 


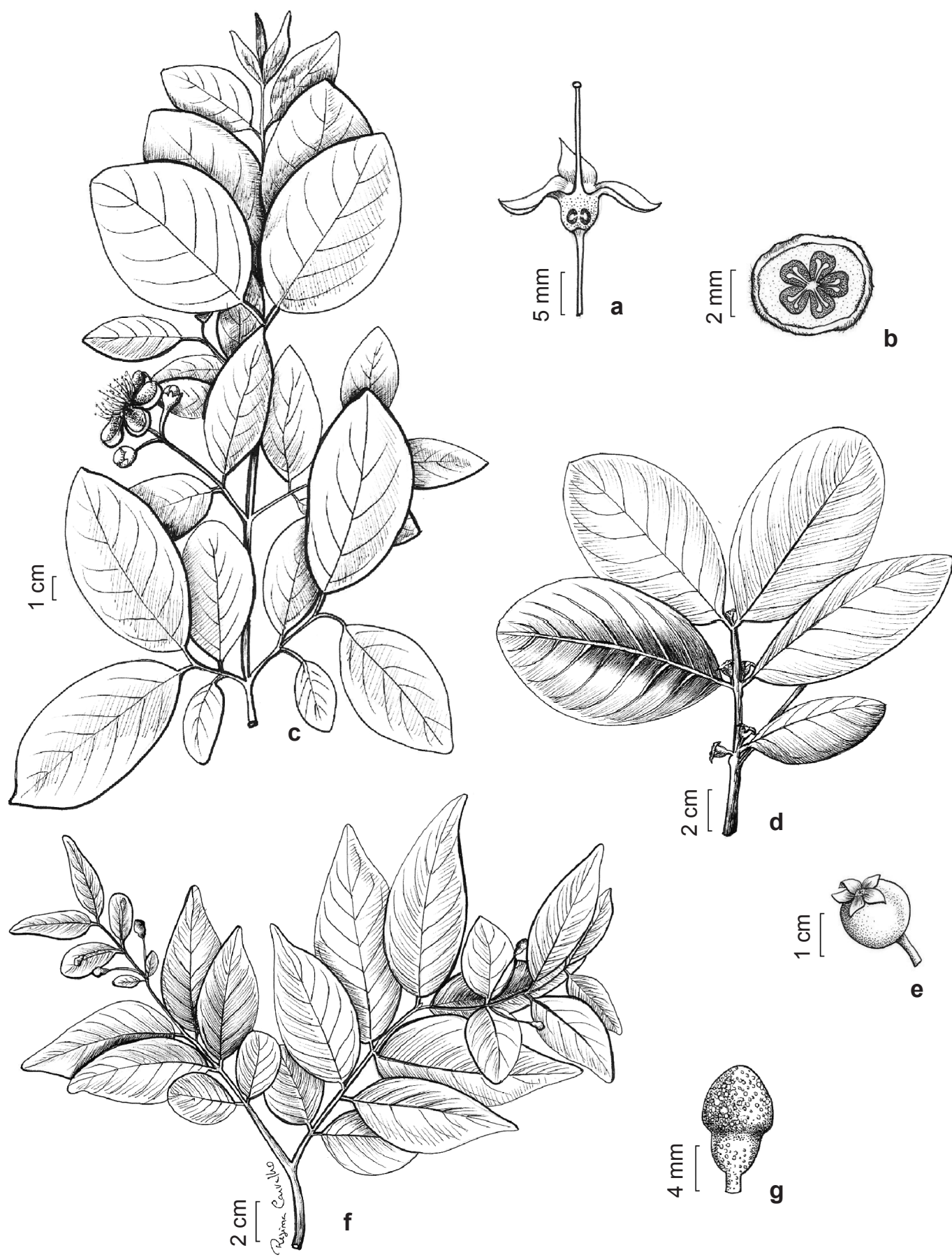

Figura 3 - Subtribo Myrtinae - a-b. Campomanesia aromatica - a. seção longitudinal da flor, mostrando o hipanto prolongado; b. seção transversal do ovário pentalocular. c. C. dichotoma - c. ramo com inflorescências. d-e. Psidium guineense - d. ramo com inflorescências; e. fruto com cálice persistente e lobos ligeiramente irregulares. f-g. P. oligospermum - f. ramo com inflorescências; g. botão floral com cálice fechado. (a-b Lourenço 255; c Lourenço 277; d-e Gadelha Neto 1985; f-g Lourenço 239).

Figure 3 - Subtribe Myrtinae - a-b. Campomanesia aromatica - a. longitudinal section of the flower, showing the prolonged hypanthium; b. transversal section of the pentalocular ovary. c. C. dichotoma - c. stem with inflorescences. d-e. Psidium guineense - d. stem with inflorescences; e. fruit with persistent calyx and slightly irregular lobes. f-g. P. oligospermum - f. stem with inflorescences; g. floral bud with closed calyx. (a-b Lourenço 255; c Lourenço 277; d-e Gadelha Neto 1985; f-g Lourenço 239). 
3-4 × 4-5 mm, ciliados; hipanto prolongado ca. de $2 \mathrm{~mm}$ acima do ovário; ca. de 10 óvulos/ lóculo. Frutos globosos ou subglobosos, ca. de $10 \mathrm{~mm}$ diâm., roxos quando maduros; sementes numerosas, ca. de $5 \mathrm{~mm}$ compr.

Material examinado: PARAÍBA: Mataraca, Millennium Inorganic Chemicals LTDA, mata de restinga, 29.I.2008, fl., I.B. Lima 872 (JPB); 23.IV.2008, fl., P.C. Gadelha Neto 2184 (JPB); 9.III.2009, fl., A.R. Lourenço 227 (JPB); fl., A.R. Lourenço 228 (JPB); 25.III.2009, fr., A.R. Lourenço 252 (JPB). RIO GRANDE DO NORTE: Baía Formosa, Mata Estrela, restinga arbustiva, 4.VIII.2004, fl., A.R. Lourenço 58 (JPB).

Ocorre nas formações vegetais da costa do Brasil, desde o Ceará até o Estado do Rio de Janeiro. $\mathrm{Na}$ área de estudo ocorre na restinga arbustiva e na restinga arbórea. A espécie distingue-se das demais pelas flores em dicásios com longos internós. Floresce de janeiro a abril, frutifica em março.

\section{Psidium L., Sp. Pl. 1: 470. 1753.}

Arbustos ou arvoretas de até $2 \mathrm{~m}$ de altura, hirtos ou vilosos, indumento simples. Flores pentâmeras, pétalas brancas; flores solitárias ou reunidas em mônades, díades ou dicásios simples, prófilos e ferófilos decíduos na antese; cálice total ou parcialmente fechado no botão floral, rompendo-se em 4-5 lobos irregulares, ligeiramente irregulares ou por meio de uma caliptra; hipanto prolongado acima do ovário; ovário 3-5 locular, numerosos óvulos/lóculo. Fruto solanídeo globoso ou piriforme, coroado pelos lobos do cálice ou por uma cicatriz circular; sementes numerosas com testa óssea.

É o maior gênero da subtribo Myrtinae, ocorrendo do México e Caribe até o norte da Argentina, com provavelmente 70 ou mais espécies, 59 delas listadas para o Brasil (Sobral et al. 2012).

\subsection{Psidium guineense Sw., Prodr.: 77. 1788.}

Fig. 3d-e

Arbustos ou arvoretas até $2 \mathrm{~m}$ de altura, ramos novos, pecíolos, nervura principal das folhas, face abaxial destas e inflorescências vilosas, indumento castanho-avermelhado; tronco com casca externa desprendendo-se em placas, caule liso castanho. Folhas oblongas, ou obovadas, ápice obtuso ou arredondado, às vezes mucronado ou curto acuminado, base arredondada a cuneada, coriáceas, discolores, opacas em ambas as faces, pontuações translúcidas densas pouco visíveis a olho nu na face adaxial, não visíveis na abaxial; 70-105 × 42-55 mm; nervura principal impressa na face adaxial, proeminente na abaxial; nervuras secundárias 7-10 pares; pecíolo 6-9 $\mathrm{mm}$ compr., canaliculado. Dicásios trifloros, díades ou mônades, axilares em nós folhosos basais; ferófilos não observados; antopódio 8-17 $\mathrm{mm}$ compr.; prófilos lineares, $2-3 \mathrm{~mm}$ compr., ciliados. Botões florais fusiformes, constrictos acima do ovário no limite com o globo petalífero, $10-15 \times 5 \mathrm{~mm}$; cálice totalmente fechado no botão floral, rompendo-se em 4-5 lobos ligeiramente irregulares; hipanto prolongado ca. de $2 \mathrm{~mm}$ acima do ovário; ovário tetralocular. Frutos globosos, até 18 mm diâm., amarelos quando maduros; sementes 2-3 mm diâm.

Material examinado: PARAÍBA: Mataraca, Millennium Inorganic Chemicals LTDA, ecótono savana-restinga, 17.XII.2009, fl. e fr., P.C. Gadelha Neto 1985 (JPB); 26.II.2009, fr., P.C. Gadelha Neto 2530 (JPB). RIO GRANDE DO NORTE: Baía Formosa, Mata Estrela, restinga arbustiva, 30.VII.2005, fr., A.R. Lourenço 68 (JPB).

Desde o México e Caribe até a Argentina. Amplamente distribuída no Brasil, sendo mais frequente em ambientes secos e antropizados. $\mathrm{Na}$ área de estudo ocorre na restinga arbustiva e no ecótono savana-restinga. Confundida com Psidium guajava L., difere desta principalmente pelas nervuras secundárias em menor número, folhas maiores e com indumento viloso na face abaxial. Floresce de novembro a dezembro, frutifica de dezembro a junho.

6.2 Psidium oligospermum DC., Prodr. 3: 236. 1828.

Fig. 3f-g

Arbusto de aprox. $2 \mathrm{~m}$ de altura, ramos jovens, pecíolos, inflorescências e botões hirtos, indumento esbranquiçado, folhas glabras; tronco acinzentado, com casca externa áspera, desprendendo-se em placas. Folhas elípticas ou eliptico-lanceoladas, ápice longo-acuminado ou agudo, base cuneada ou arredondada, cartáceas ou coriáceas, discolores, brilhantes na face adaxial, opacas na abaxial, pontuações translúcidas densas visíveis a olho nu; 34-55 × 10-25 mm; nervura principal impressa na face adaxial, proeminente na abaxial; nervuras secundárias pouco visíveis na face adaxial, visíveis na abaxial, 5-8 pares; nervura marginal $1-3 \mathrm{~mm}$ do bordo; pecíolo $2-5 \mathrm{~mm}$ compr., não canaliculado. Flores em díades ou mônades axilares em nós 
folhosos áfilos ou basais; ferófilos não observados; antopódio 7-15 mm compr.; prófilos lineares, 1-2 $\mathrm{mm}$ compr., ciliados. Botões florais obcônicos ou piriformes, ligeiramente constritos acima do ovário, no limite com o globo petalífero, 7-8 $\times$ 4-6 mm; cálice total ou parcialmente fechado no botão floral, rompendo-se em 4-5 lobos irregulares, através uma abertura apical, ou através de uma caliptra, gerada pelo rompimento na constrição acima do ovário; hipanto prolongado ca. de 1-1,5 $\mathrm{mm}$ acima do ovário; ovário trilocular. Frutos piriformes ou globosos, até $15 \mathrm{~mm}$ diâm., amarelos quando maduros; sementes de 1 a várias, até ca. 6 mm compr.

Material examinado: PARAÍBA: Mataraca, Millennium Inorganic Chemicals LTDA, ecótono savana-restinga, 30.IX.2008, fr., A.R. Lourenço 205 (JPB); 9.III.2009, fl., A.R. Lourenço 235 (JPB); fl. e fr., A.R. Lourenço 239 (JPB); restinga arbustiva, fr., A.R. Lourenço 241 (JPB); ecótono savana-restinga, 29.V.2009, fr., A.R. Lourenço 270 (JPB); 23.IV.2008, fl., P.C. Gadelha Neto 2178 (JPB); 26.II.2009, fl., P.C. Gadelha Neto 2552 (JPB).

Ocorre no Rio Grande do Norte, Paraíba, Pernambuco e Bahia, na Mata Atlântica e na Caatinga. $\mathrm{Na}$ área de estudo ocorre na restinga arbustiva e no ecótono savana-restinga. Distinguese facilmente de Psidium guineense pelas folhas com ápice longo-acuminado, glabras. Floresce de fevereiro a abril, frutifica de maio a setembro.

\section{Agradecimentos}

Aos colegas Marccus Alves e Marli Pires Morim, as sugestões na primeira revisão do manuscrito; à destilaria Baía Formosa e a Millennium Inorganic Chemicals LTDA o acesso as áreas de coleta; ao CNPq, as bolsas de mestrado e de produtividade em pesquisa concedidas, respectivamente, à primeira e segunda autora, e à ilustradora Regina Carvalho.

\section{Referências}

Araújo, D.S.D. 2000. Análise florística e fitogeográfica das restingas do Estado do Rio de Janeiro. Tese de Doutorado. Universidade Federal do Rio de Janeiro, Rio de Janeiro. 176p.

Barroso, G.M. et al. 1991. Sistemática de angiospermas do Brasil. Vol. 3. UFV, Viçosa. 326p.

Barroso, G.M. \& Peixoto, A.L. 1995. Myrtaceae na Reserva Florestal de Linhares, ES, Brasil - gêneros Calyptranthes e Marlierea. Boletim do Museu de Biologia Melo Leitão (N. Ser.) 3: 3-38.

Barroso, G.M. \& Peron, M. 1994. Myrtaceae. In: Lima, M.P.M. \& Guedes-Bruni, R.R. (orgs.). Reserva
Ecológica Macaé de Cima, Nova Friburgo, RJ. Aspectos florísticos das espécies vasculares. Jardim Botânico do Rio de Janeiro, Rio de Janeiro. Pp. 261-296.

Barroso, G.M.; Morim, M.P.; Peixoto, A.L. \& Ichaso, C.L.F. 1999. Frutos e sementes: morfologia aplicada à sistemática de dicotiledôneas. Ed. Universidade Federal de Viçosa, Viçosa. Pp. 227-231.

Berg, O. 1857. Myrtaceae. In: Martius, C.F.P. von (ed.). Flora brasiliensis. Munchen, Wien, Leipzig. Vol. 14, pars 1, pp. 1-468.

Berg, O. 1858. Myrtaceae. In: Martius, C.F.P. von (ed.). Flora brasiliensis. Munchen, Wien, Leipzig. Vol. 14, pars 1, pp. 469-528.

Berg, O. 1859. Myrtaceae. In: Martius, C.F.P. von (ed.). Flora brasiliensis. Munchen, Wien, Leipzig. Vol. 14, pars 1, pp. 529-656.

Briggs, B.G. \& Johnson, L.A.S. 1979. Evolution in the Myrtaceae-Evidence from inflorescence structure. Proceedings of the Linnean Society of New South Wales 102: 157-256.

Embrapa Solos UEP. 2006. Solos do nordeste. Disponível em < http://www.uep.cnps.embrapa.br/ solos/>. Acesso em 10 Mar 2007.

Faria Júnior, J.E.Q. 2010. O gênero Eugenia L. (Myrtaceae) nos Estados de Goiás e Tocantins, Brasil. Dissertação de Mestrado. Universidade Federal de Brasília. 250p.

Font Quer, P. 1979. Diccionario de botánica. $7^{\circ}$ ed. Editorial Labor, Barcelona.

Freire, M.S.B. 1990. Levantamento florístico do Parque Estadual das Dunas do Natal. Acta Botanica Brasilica 4: 41-59.

Govaerts, R.; Sobral, M.; Ashton, P.; Barrie, F.; Holst, B.K.; Landrum, L.L.; Matsumoto, K.; Mazine, F.F.; Nic Lughadha, E.; Proença, C.; Soares-Silva, L.H.; Wilson, P.G. \& Lucas, E. 2008. World checklist of Myrtaceae. Kew Publishing, Royal Botanic Gardens, Kew.

Hickey, L.J. 1973. Classification of the architecture of Dicotyledonous leaves. American Journal of Botany 60: 17-33.

Holst, B.K.; Landrum, L.; Grifo, F. 2005. Myrtaceae. In: Berry, P.E.; Yatskievych, K. \& Holst, B.K. (orgs.). Flora of Venezuelan Guayana v. 7. Missouri Botanical Garden Press, St. Louis.

Jacomine, P.K.T., Almeida, J.C. \& Medeiros, L.A.R. 1971. Levantamento exploratório - reconhecimento de solos do estado do Rio Grande do Norte. Bl. Téc. 21 - MA-SDN. Recife.

Landrum, L.R. 1986. Campomanesia, Pimenta, Blepharocalyx, Legrandia, Acca, Myrrhinium and Luma, Myrtaceae. Flora Neotropica 45: 1-178.

Landrum, L.R., \& Kawasaki, M.L. 1997. The genera of Myrtaceae in Brazil: an illustrated synoptic 
treatment and identification keys. Brittonia 49: 508-536.

Legrand, C.D. \& Klein, R.M. 1969. Mirtáceas: 3. Myrcia. In: Reitz, R. (ed.). Flora Ilustrada Catarinense. Pp. 217-330.

Mabberley, D.J. 1997. The plant Book - A portable dictionary of the vascular plants. 2 ed. Cambridge University Press. 858p.

Mc Vaugh, R. 1958. Flora of Peru - Myrtaceae. Field Museum publications in botany 13: 569-818.

Mc Vaugh, R. 1963. Flora da Guatemala. Fieldiana: Botany 24: 283-405.

Mc Vaugh, R. 1968. The genera of American Myrtaceae - an interim report. Taxon 17: 354-418.

Mc Vaugh, R. 1969. The botany of Guyana highlandPart VIII - Myrtaceae. Memoirs of The New York Botanical Garden 18: 55-286.

Oliveira-Filho, A.T. \& Carvalho, D.A. 1993. Florística e fisionomia da vegetação no extremo norte do litoral da Paraíba. Revista Brasileira de Botânica 16: 115-130.

Peixoto, A.L. \& Gentry, A. 1990. Diversidade e composição florística da mata de tabuleiro na Reserva Florestal de Linhares (Espírito Santo, Brasil). Revista Brasileira de Botânica 13: 19-25.

Reitz, R.; Klein, R.M. \& Reis, A. 1978. Projeto madeiras de Santa Catarina. Herbário Barbosa Rodrigues, Itajaí. 320p.

Ribeiro, J.E.L.S.; Hopkins, M.J.G.; Vicentini, A.; Sothers, C.A.; Costas, M.A.S.; Brito, J.M.; Souza, M.A.D.; Martins, L.H.P.; Lohmann, L.G.; Assunção, P.A.C.L.; Pereira, E.C.; Silva, C.F.; Mesquita, M.R. \& Prócopio, L.C. 1999. Flora da Reserva Ducke: guia de identificação das plantas vasculares de uma floresta de terra-firme na Amazônia Central. Amazonas, INPA-DFID. 800 p.

Silva, S.M.; Britez, R.M.; Souza, W.S. \& Joly, C.A. 1994. Fitossociologia do componente arbóreo da floresta de restinga da Ilha do Mel, Paranaguá, Paraná. Anais do III Simpósio de Ecossistemas da Costa Brasileira 3: 33-48.

Soares-Silva, L.H. 2000. A família Myrtaceae-subtribos: Myrciinae e Eugeniinae na Bacia Hidrográfica do Rio Tibagi, Estado do Paraná, Brasil. Tese de Doutorado. Universidade de Campinas, Campinas.

Sobral, M.; Proença, C.; Souza, M.; Mazine, F. \& Lucas, E. 2012. Myrtaceae. In: Forzza, R.C. et al. Lista de espécies da flora do Brasil. Jardim Botânico do Rio de Janeiro. Disponível em $<$ http://floradobrasil.jbrj. gov.br/2012/FB010660>.

Stearn, W.T. 1978. Botanical Latin. $2^{\circ}$ impr. Timber Press, Portland. 546p.

Thiers, B. [continuously updated]. Index Herbariorum: a global directory of public herbaria and associated staff. New York Botanical Garden's virtual herbarium. Disponível em $<$ http://sweetgum.nybg. org/ih/>. Acesso em Mai 2009.

Wilson, P.G.; O’Brien, M.M.; Gadek, P.A. \& Quinn, C.J. 2001. Myrtaceae revisited: a reassessment of infrafamilial groups. American Journal of Botany 88: 2013-2025.

Zickel, C.S.; Vicente, A.; Almeida Jr., E.B.; Cantarelli, J.R. \& Sacramento, A.C. 2004. Flora e vegetação das restingas no Nordeste brasileiro In: EskinaziLeça, E.; Neumann-Leitão, S. \& Costa, M.F. (eds.). Oceanografia: um cenário tropical. Bargaço, Recife. Pp. 689-701. 